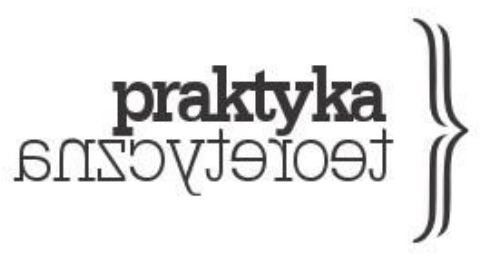

ISSN 2081-8130

DOI: $10.14746 /$ prt.2016.2.7 www.praktykateoretyczna.pl

\title{
DO FABRYKI! LENIN NEGRIEGO I CIĘCIE PODMIOTOWE (1968-73)
}

\author{
MICHAEL HARDT
}

\begin{abstract}
Abstrakt: Tekst stanowi fragment doktoratu Michaela Hardta Sztuka organizacji: źródta ontologii politycznej u Gilles'a Deleuze'a i Antonio Negriego. Autor analizuje w nim dialog, jaki Antonio Negri podejmuje z pismami Włodzimierza Lenina w okresie intensywnych walk społecznych i przekształceń składu klasowego we Włoszech w latach 1968-1973. Doszukując się w tym spotkaniu kluczowego zwrotu teoretycznego w myśli włoskiego marksisty, Hardt przekonuje, że to właśnie w tekstach rosyjskiego rewolucjonisty Negri odnalazł narzędzia pozwalające mu wyjść poza ograniczenia krytycznego marksizmu, uznającego klasę robotniczą przede wszystkim za obiekt wyzysku, przez uczynienie kwestii jej podmiotowości centralnym zagadnieniem i punktem wyjścia teorii.
\end{abstract}

Słowa kluczowe: klasa robotnicza, skład klasowy, podmiot rewolucyjny, organizacja, spontaniczność mas. 
Intensywność walk robotniczych i studenckich roku 1968 zaskoczyła cały świat. Włochy okazały się jednak, pod wieloma względami, anomalią. W 1968 i 1969 roku mieliśmy do czynienia z ciagłym rewolucyjnym crescendo; walki trwały, w różnych formach, przez kolejnych dziesięć lat. Jednym z symbolicznych dla ówczesnych ruchów wydarzeń był konflikt na Corso Traiano z września 1969, kiedy to doszło do brutalnych starć demonstrantów z policją. Powaga sytuacji konsekwentnie rosła przynajmniej do roku 1973; robotnicy Fiata znów reprezentowali symboliczne centrum: „29 i 30 marca 1973 roku w Mirafiori, w Rivalii, we wszystkich turyńskich oddziałach Fiata: bezwarunkowy strajk przeszedł w zbrojną okupację" (Negri 1974, 189).

W oczach Negriego eksplozja „czerwonego dwulecia” i kolejnych lat mogła wydawać się niespodziewana, ale tylko pod względem intensywności czy gwałtowności. Stała się potwierdzeniem jego nadziei i intuicji, a zarazem je przekroczyła, wymuszając radykalne przyśpieszenie na planie zmiany społecznej; dała myśli Negriego nowe życie i narzuciła jej rygorystyczny rytm. „Rewolucyjna tęsknota”, której doświadczył w fabrykach lat sześćdziesiątych, a która wydawała się rosnąć w przemysłowej klasie robotniczej od rewolty na Piazza Statuto z 1962 roku, wybuchła teraz gwałtownie w całym społeczeństwie. W całym kraju pojawiła się niezliczona ilość nowych organizacji politycznych zrzeszających robotników i studentów: Potere operaio [Siła robotnicza], Lotta continua [Walka trwa], il Manifesto, itp. Żądanie głębokiej zmiany społecznej i intensywne pragnienie utopii pociągnęły za soba bezpośrednie działania. Negri wraz z kolegami musieli się natrudzić, by dotrzymać kroku walkom, by odszyfrować zmieniającą się rzeczywistość społeczną. W ich rozumieniu nie doświadczali wcale włoskiej wersji roku 1905 w Rosji - próby generalnej jakiegoś nadchodzącego wydarzenia; były to „dni kwietniowe”, namacalne preludium rewolucji. Uważali więc, że ich rolą jako intelektualistów powinno być rozjaśnienie i nadanie teoretycznej spójności kierunkowi, w którym zmierzają masowe walki, po to, aby popchnąć dalej ich cele i kształtować nowo wyłaniające się normy kolektywnych zachowań; w żywiołowości walk szukali porządku. Co więcej, czuli się w obowiązku dążyć do urzeczywistnienia szczególnych możliwości wynikających z włoskiej anomalii: „Tu, gdzie klasa robotnicza jest najsilniejsza, wszystko zależy od nas” (Negri 1974,158). W tym punkcie, Negri wraz ze swymi intelektualnymi towarzyszami ostatecznie wychodzą z uniwersytetu i wchodzą do fabryki. 
Zgodnie z powyższymi uwagami musimy zmodyfikować naszą metodę lektury Negriego tak, by uwzględnić warunki budowania teorii w tym okresie. Umknie nam bowiem coś bardzo wartościowego, jeśli zapomnimy o silnym entuzjazmie i potrzebie natychmiastowych działań, którą czuł Negri wraz z towarzyszami. W pismach z tego okresu powinniśmy zwracać uwagę na dwa najważniejsze aspekty: ich doraźność jako politycznej interwencji oraz dążenie do stania się głosem kolektywnym. To, co z perspektywy dwudziestu lat może się nam wydawać nadmuchaną retoryką, w ówczesnych ruchach społecznych pełniło rzeczywistą funkcję organizacyjną. Prace Negriego są pełne sloganów i haseł. Niektóre wymyślił sam, niektóre zaczerpnął z żywiołu dyskursu politycznego; z jednej strony celem było zaprezentowanie swoich argumentów w sposób powszechnie zrozumiały dla ruchów społecznych, by mogły się one przyczyniać do rzeczywistych walk. Z drugiej - o to, by dać realną podbudowę i solidne teoretyczne umocowanie temu dyskursowi i jego praktycznemu oddziaływaniu. Negri był w pełni świadomy swojej roli wewnątrz ruchu: roli intelektualisty. Dlatego też starał się włączyć do swojego dyskursu główne idee i pojęcia przynależne ruchom społecznym, tak by móc usytuować je i rozwijać w obrębie spójnej siatki pojęciowej. W wielu przypadkach widać, że Negri próbuje po prostu utrzymać się na powierzchni wartkiego nurtu ruchów społecznych. Jego prace tracą wtedy naukowy ton, a takie formalności jak przypisy znikają zupełnie. Wybrzmiewa w nich raczej kolektywny głos politycznego programu, ciagłe podkreślanie „,naszych bezpośrednich zadań”. Od takiego typu prac nie powinno się wymagać takiej samej oryginalności, co od indywidualnych wysiłków teoretycznych. Można powiedzieć, że oryginalność opiera się tu przede wszystkim na wysiłku podążania za intelektem mas i przekładania go na efektywne formy polityczne. Negri chciał, by część siły tych walk została zawarta w jego głosie. Gdybyśmy jednak chcieli przeprowadzić genealogię różnych myśli i linii argumentacyjnych, tak by zobaczyć, kiedy Negri przedstawiał oryginalne pomysły, a kiedy po prostu powtarzał krążące poglądy, potrzebowalibyśmy pogłębionych badań historycznych tamtego okresu, rzetelnych analiz dotyczących praktyk różnorakich organizacji. Najważniejsza jest tu zapewne kwestia walki zbrojnej (szczególnie dla tych, których interesuje aspekt kryminalny), ale jest to także sprawa najbardziej zawiła: adekwatna analiza wymagałby szeroko zakrojonych studiów historycznych. Te wykraczaja jednak poza zakres naszych obecnych rozważań i będą musiały zostać podjęte w przyszłych pracach $^{1}$.

1 Nota wydawcy: Chociaż Hardt nie rozwiną tej ścieżki poszukiwań w swojej pracy, inni badacze poszli 
Kolejnym punktem, który musimy wziąć pod uwagę analizując pisma Negriego z tamtego okresu, jest ich polityczna bezpośredniość. Horyzont ówczesnych ruchów politycznych wydawał się być w ciągłm ruchu, a każde zdarzenie wymuszało niecierpiące zwłoki decyzje. Tekstów nie datowano latami, ale miesiącami. Negri czuł potrzebę bieżącego interpretowania wydarzeń. We wrześniu 1971 roku przygotowuje artykuł „Kryzys PaństwaPlanisty” na trzecią „Konferencję poświęconą organizacji” przygotowaną przez Potere Operaio. Komentuje w nim ustawy Nixona dotyczące parytetu wymienialności (incontrovertibility) dolara na złoto, które weszły w życie w sierpniu - czyli miesiąc wcześniej. Grafik był napięty i Negri zdawał sobie sprawę, że ten stan ciagłego pośpiechu obecny był w jego pisaniu.

\begin{abstract}
Możliwe, że słabości tego eseju - jego bezpośrednie powiązanie z problemami organizacji, być może zbytnia polemiczność i skrótowość w tej próbie nadążenia za przygodnością politycznej dyskusji - okażą się jego mocnymi stronami; jeżeli tylko prawda jest, że zorganizowana praktyka rewolucyjna jest nie tylko jedyną droga do naukowego zrozumienia rzeczywistości, ale także jedynym sposobem, by tę rzeczywistość przybliżyć (Negri 1988, 96).
\end{abstract}

Negri próbuje podporządkować dyskurs teoretyczny bieżącym wymogom praktycznym - tak, by wraz z rozluźnianiem uczonego rygoru zyskać konkretny wpływ na rzeczywistość.

Nowe podejście teoretyczne Negriego w tamtym okresie, można czytać jako próbę przepracowania marksistowskiej siatki pojęciowej - przejścia od krytycznego marksizmu do czegoś, co nazywam „marksizmem projektującym”. We wcześniejszych rozdziałach wspominaliśmy już, że w ramach marksizmu krytycznego pozytywny projekt proletariatu jest zawsze podporządkowany krytyce kapitału². Projekt ten może zaistnieć tylko w przyszłości, jako rezultat krytyki w dialektycznym ruchu zniesienia kapitału. Natomiast postulowanie takiego projektu w teraźniejszości, poza kontekstem dialektycznym, z perspektywy teorii krytycznej jest myśleniem czysto utopijnym. O ile wcześniej taka perspektywa wydawała się Negriemu problematyczna, o tyle po 1968 roku stała się dla niego kompletnie niemożliwa do obrony. Negri był wtedy świadkiem cyklu walk, które były wyrazem wyłonienia się

tą drogą, śledząc i analizując konwergencje, dywergencje, wpływy i zapożyczenia, które w tym okresie dotyczą Negriego, jego sojuszników i jego wrogów. Zob. Wright 2002, a także Borio, Pozzi i Roggero 2002.

2 Nota edytorska: Hardt odnosi się w tym miejscu do rozdziału swojego doktoratu „Cisza przed burzą: marksizm krytyczny (1964-1968)", w którym zajmuje się korzeniami filozofii i działalności Negriego w pierwszym okresie operaizmu. Rozdział ten nie został opublikowany. Analizuje się w nim krytykę kapitału, która przeprowadza Negri - kapitału pod postacią Keynesowskiego centralnego planowania i normatywnego formalizmu prawnego Kelsena. Towarzyszy temu równoległy, afirmatywny projekt, który ma na celu zerwanie z czysto negatywnym podejściem innych nurtów krytycznego marksizmu, takich jak Szkoła Frankfurcka. 
czy dojrzenia podmiotowości klasy robotniczej, domagającej się własnego projektu politycznego na własnych warunkach $-\mathrm{z}$ dala od obiektywnej, krytycznej siatki pojęciowej. W tym wypadku obiektywna krytyka kapitału musi zostać podporządkowana subiektywnym potrzebom i pragnieniom klasy pracującej. Potrzebne jest więc nowe podejście, aby wykonać skok, do którego niezdolna jest sama krytyka. Lenin zdawał się oferować Negriemu wgląd niezbędny do rozwinięcia innego podejścia do marksizmu - bardziej odpowiadającą bieżącym wymaganiom. Wybuch walk społecznych połączony z leninowską lekturą Marksa wykształcił u Negriego zupełnie antyalthusserowską postawę. Jeśli więc istnieje cięcie epistemologiczne, które rozdziela „młodego Marksa” od Marksa dojrzałego, to polega ono na rzeczywistym pojawieniu się (a nie zniknięciu) podmiotu rewolucyjnego; jest momentem, w którym „analiza wyzwala się z warunków swojego istnienia, aby przemienić się w program” (Negri 1974, 102). Dla Negriego punktem krytycznym jest nie tyle epistemologia, co podmiotowość: „daleka od skończenia na »procesie bez podmiotu«, ewolucja myśli marksistowskiej idzie w przeciwną stronę - jest ciągle blisko rzeczywistości organizującego się podmiotu rewolucyjnego" (Negri 1974, 103, n.7). Perspektywa leninowska wraz ze zwiększająca się presją ruchów robotniczych wyznacza u Negriego moment cięcia podmiotowego.

\section{Kryzys Państwa-planisty}

Dociekania Negriego dają nam wystarczająco dużo argumentów, aby podać w wątpliwość metody krytycznego marksizmu - głównie ze względu na to, że nie pozwala, by podmiotowy punkt widzenia klasy robotniczej odgrywał główną rolę w procesie krytycznym. Jednak w okresie teoretycznego i politycznego kryzysu Negri wciąż odwołuje się do tego nurtu. Kryzys krytycznego marksizmu nie oznacza bowiem, że należy go całkowicie zanegować. Chodzi tu raczej o zmianę ukierunkowania, o osadzenie argumentacji w innym kontekście: tak jak we wcześniejszych okresach projekt robotniczy podporządkowany był krytyce kapitału, tak teraz krytyka musi zostać podporządkowana projektowi. Dokładną formę, jaka przybiera ta inwersja, zobaczymy później. Na razie jednak, używając ram pojęciowych krytyki państwa i kapitału wypracowanych w ramach wcześniejszych studiów, Negri stara się zdefiniować nowe stosunki sił, które wyłoniły się z kolejnego cyklu walk rozpoczętego w roku 1968. Po raz kolejny, celem jest uchwycenie zmian form państwowych i kapitalistycznych systemów kontroli - możliwe jest to dzięki krytyce opartej na tym, w jaki sposób kapitał czyta sam siebie.

Państwo uległo zmianie: z modelu opartego na wyznacznikach ekonomicznych keynesizmu przeistoczyło się w „państwo kryzysowe”. Nie oznacza to jednak, że kapitał 
znalazł się na skraju upadku - w kryzysie nie ma nic z katastrofy. Negri podkreśla raczej fakt, że państwo odeszło od strategii stabilności (produkcji, kontroli rynków, polityki monetarnej itd.), która wcześniej zapewniała rozwój wielkiego przemysłu. Z tych przeobrażeń wynikaja nowe problemy, nie tylko dla wielkiego przemysłu. Zerwany zostaje także społeczny kontrakt oparty na planowaniu; dobiegają końca starania kapitału, by - przez kolektywne, instytucjonalne negocjacje, będące jednocześnie formą kontroli i legitymizacji - wchodzić w interakcję z klasą robotniczą. Nadejście państwa neoliberalnego nie wiążą się jednak ze zmniejszeniem ekonomicznego i społecznego interwencjonizmu. Przeciwnie, następuje zwiększenie społecznej siły pracy i wzmożenie kontroli państwa nad społeczną fabryką. Nowatorskim elementem, charakterystycznym dla państwa kryzysowego jako podmiotu regulującego rozwój, jest przyswojenie przez nowego stopnia autonomii, jako podmiotu regulującego rozwój zewnętrzny wobec wszelkiego bezpośredniego stosunku między kapitałem a praca. Zmiany te dążą do usunięcia jakiegokolwiek organicznego stosunku zapośredniczenia między klasą robotniczą a państwem, reprezentującym zbiorowy kapitał. „Rozdzielenie oraz jednostronność stosunku między pracą a dowodzeniem nią zostają doprowadzone do granic możliwości; państwo musi stać się państwem kryzysowym, w którym egzekwuje i zarządza swą własną wolnością do dowodzenia, aby system mógł przetrwać jako całość” (Negri 1988, 119). Kiedy obustronny proces ekonomicznej i prawnej organizacji, który umożliwiał organiczny stosunek między kapitałem a praca, zostaje porzucony, kryzys staje się zwyczajnym czynnikiem rozwoju kapitału i jego rządów.

Negri argumentuje, że na przemianę formy państwa wskazuje także to, co stało się z funkcja pieniądza i państwowymi politykami monetarnymi. Analizy te są zainspirowane nowym odczytaniem „Rozdziału o pieniądzu” z Grundrisse(Marks 1986, 63-168), który Negri próbuje odnieść do współczesnej sytuacji, by zbadać relację między produkcją wartości i mechanizmami legitymizacji (Negri 1974, 107-102; Negri 1988). W systemie kapitalistycznym pieniądz jawi się jako uniwersalny ekwiwalent, jako forma mediacji w wymianie między praca a kapitałem. Jednak generalna tendencja kapitalistycznego rozwoju polega na oswobodzeniu pieniądza z funkcji mediacji (jako uniwersalnej reprezentacji wartości wymiennej) i spowodowaniu, by pieniądz służył jako bezpośrednia siła produkcji i władzy. Dla Negriego ustawy Nixona z 1971 dotyczące oderwania dolara od standardu złota są znamiennym przykładem realizacji tej tendencji. Stabilność kursów wymiany walut gwarantowała równowage na rynkach finansowych, konieczną w przypadku planowania 
produkcji na masową skalę; decyzja, by zrezygnować z polityki zestandaryzowanej wymiany oznacza upadek Keynesowskiego państwa-planisty, w tym sensie, że podważa się jeden z podstawowych warunków istnienia takiej polityki, czyli stabilne rynki wymiany. Zmieniająca się rola pieniądza wiąże się ze zmianami w obrębie samej formy wartości. Państwo-planista opiera się na tym, co Negri nazywa „prawem wartości”, które ustanawia generalną równoważność (parity) między kapitałem a praca. Jak widzieliśmy w poprzednich rozdziałach, praca jest jedynym źródłem wartości w strukturze kapitalistycznej - a przez to i Grundnorm prawa $^{3}$. Negocjacje zbiorowe oraz dialog zapośredniczony przez związki zawodowe i państwo zapewniają prawu wartości instytucjonalne umocowanie i stabilność. Decyzja, by zdestabilizować rynki finansowe postawiła pod znakiem zapytania nie tylko mediująca funkcję pieniądza jako uniwersalnego ekwiwalentu, ale także pośredniczącą funkcje państwa i związków zawodowych (w kwestiach dotyczących sprzedaży siły roboczej, ustanawiania prawa, itd.) (Negri 1988, 139). Zwrot w polityce monetarnej wskazuje więc na głębszy kryzys prawa wartości, który destabilizuje proces produkcji i delegitymizuje relacji władzy.

Zgodnie z tezami operaizmu (które omówiliśmy w poprzednim rozdziale ${ }^{4}$ ), Negri argumentuje, że powyższe zmiany w obrębie kapitału i państwa kapitalistycznego mogą być zrozumiałe tylko wtedy, jeśli będziemy traktowali ruchy robotnicze jako bodziec rozwojowy; kapitał nigdy nie posuwa się przecież do przodu sam z siebie. W schematycznej formie (typowej dla Negriego), można powiedzieć, że tak jak rok 1917 popchnął kapitał w stronę roku 1929 i zmusił go do wykształcenia państwa-planisty w latach trzydziestych XX wieku, podobnie naciski roku 1968 spowodowały zwrot monetarystyczny w 1971 roku i rozwój państwa kryzysowego w latach siedemdziesiątych XX wieku. Po raz kolejny kapitał stara się więc zreorganizować swoje struktury kontroli, podporządkowując sobie zagrożenie ze strony robotników i włączając je w kontinuum rozwoju dialektycznego (kapitalistyczne strukturyzowanie -> destrukturyzacja robotnicza $->$ kapitalistyczna restrukturyzacja).

3 Nota wydawcy: Hardt odnosi się tu do analiz z poprzedniego rozdziału, w którym przywołana zostaje przeprowadzona przez Negriego krytyka neutralizującej definicji pracy we włoskiej konstytucji. Według Negriego praca powinna funkcjonować jako coś, co Kelsen nazwał Grundnorm (norma podstawowa), z której wyprowadzona zostaje cała struktura prawna państwa.

4 Nota wydawcy: Tezy, do których odnosi się Negri brzmią następująco: 1) teza o „kierowniczej roli”, wedle której krytykę kapitału należy rozpoczynać od walk klasowych, ponieważ to one napędzają kapitalistyczny rozwój; 2) strategia „najmocniejszego ogniwa”, która wymaga, by rewolucyjna energia skupiła się nie na leninowskim „najsłabszym ogniwie systemu kapitalistycznego”, ale na najmocniejszym ogniwie łańcucha ruchu robotniczego; 3) taktyka „odmowy pracy”, która ustanawia natychmiastowe zniesienie kapitalistycznych relacji produkcji, dzięki strajkom, sabotażowi, bezpośredniemu przywłaszczeniu, miganiu się od pracy i emigracji. 
Z czysto finansowego punktu widzenia ofensywa płacowa robotników zmiotła iluzję społecznej homeostazy i strukturalnej stabilności, będących wynikiem kapitalistycznego planowania i negocjacji. Żądania płacowe podważyły podstawy stabilności polityki pieniężnej i doprowadziły kapitał do granic możliwości utrzymania równowagi w obrębie jego własnej kontroli (Negri 1974, 115). Jednak, znów, lepiej zrozumiemy tę sytuację, jeśli spojrzymy na nią szerzej, tym razem przez pryzmat wartości. Zniszczeniu państwa-planisty jako podmiotu władzy służą nie tylko żądania płacowe stawiane poszczególnym pracodawcom, ale także żądania kontroli społecznego procesu produkcji i reprodukcji stawiane zbiorowemu kapitałowi i państwu. W nowym cyklu walk zorganizowana klasa robotnicza stała się tak dużym zagrożeniem dla kapitału, że ten zmuszony był porzucić swój projekt stabilności aby się bronić, musiał zniszczyć własną formę rządzenia. Innymi słowy, kapitał musiał porzucić teorię, w której jedynym źródłem wartości była praca. Pracę trzeba było „zdewaloryzować”, by przeciwstawić się dobrze zorganizowanej klasie robotniczej. Demonetaryzacji kapitału towarzyszyła więc dewaloryzacja pracy. W praktyce oznaczało to początek nowych czasów: innowacji technologicznych, dalszej mechanizacji i komputeryzacji przemysłu ciężkiego, co pociagnęło za sobą rozproszenie masowej siły roboczej, która okazała się być tak silnym przeciwnikiem. Aby oddalić zagrożenie ze strony robotników, aby zniszczyć warunki, w których się organizuja, kapitał zmuszony jest skierować swoją uwagę z pracy żywej na martwą pracę masowej produkcji, a tym samym ucierpieć na skutek spadającej stopy zysku5. Kryzys struktur produkcji masowej zapowiada więc nowy projekt kapitalistycznej restrukturyzacji.

Warto zaznaczyć, że kiedy Negri po raz pierwszy podkreślał, że lata siedemdziesiąte XX wieku stanowia punkt zwrotny warunków produkcji kapitalistycznej i roli państwa, jego tezy były uważane za radykalne i kontrowersyjne. Nie są już takie dziś. Intuicje Negriego z wczesnych lat transformacji zostały szeroko potwierdzone przez współczesnych ekonomistów. Interpretacja, wedle której wczesne lata siedemdziesiąte XX wieku były okresem, w którym zniszczono warunki masowej produkcji, a kapitał zaczął szukać sobie nowych podstaw, należy dziś do mainstreamu. Weźmy na przykład książkę Charles'a Sabela i Michaela Piore The Second Industrial Divide z 1984 roku. Autorzy reprezentujący kapitalistyczny punkt widzenia proponuja tę samą periodyzację i chociaż nie określają

5 Negri przywołuje tu klasyczny marksistowski argument. Wartość dodatkowa, w rozumieniu Marksa, może być wyciskana tylko z pracy żywej. Wraz z zastępowaniem pracy żywej przez maszyny, kapitałowi zmniejszy się rezerwuar, z którego można czerpać wartość dodatkową. Będzie więc zmuszony podwyższać stopę wartości dodatkowej wyciskanej z mniejszej ilości pracy lub będzie musiał zmierzyć się ze spadkiem zysku. Wyjaśnienie Negriego zob. Negri 1974, 107-15. 
tamtego czasu mianem okresu państwa-kryzysowego, to ich koncepcja „elastycznej produkcji" ma w sobie wiele z rozpoznań Negriego ${ }^{6}$. Jednak nawet jego analizy dotyczące zbiorowego kapitału i państwa są ograniczone obiektywistycznym podejściem teorii krytycznej; krytyka ekonomii politycznej nie potrafi adekwatnie ująć aktualnej klasy pracującej jako konkretnej podmiotowości. Natomiast perspektywa operaistyczna pozwala dostrzec w klasie robotniczej bodziec dla kapitalistycznego rozwoju, ale w formie zbyt abstrakcyjnej; albo inaczej - krytyka ekonomii politycznej rozpoznaje klasę pracująca głównie jako obiekt wyzysku, ale nigdy nie udaje się jej w pełni ukazać jej jako sprawczego podmiotu. Ale intensywne walki polityczne we Włoszech skłoniły Negriego do spojrzenia pozą tę krytykę - w stronę teorii, która skupi się na podmiotowości klasy robotniczej. Osią tej nowej refleksji byłoby przejście od krytyki ekonomii politycznej do teorii organizacji. W owym zamierzeniu Lenin wydaje się być oczywistym sojusznikiem - tym, który skutecznie wykorzystał siłę proletariatu jako podmiotu rewolucyjnego.

\section{Spontaniczność i podmiotowość: Leninowska organizacja 1}

Studia nad Leninem były dla Negriego do pewnego stopnia wymogiem czasów - elementem dyskursu ówczesnych bojowników. W wywiadzie udzielonym w więzieniu w 1979 roku tak tłumaczy ten krok w swojej intelektualnej biografii: „Leninizm jest dla mnie ceną, która musieliśmy zapłacić wobec składu politycznego włoskiego proletariatu. Nie dawało się mówić o polityce inaczej niż przez leninizm... To była klasowa lingua franca: mogła sprawiać kłopoty, ale tylko dzięki niej można było zrobić jakiś postęp z klasą (i z nikim innym)" (Bocca 1980, 166). Leninizm wisiał w powietrzu, był częścią kultury ruchów oddolnych. Negri w dużej mierze wyolbrzymia sprawę - być może czuje presję różnych kryminalnych powiązań: ale faktem jest, że nawet jeśli początkowo mógł czuć się przymuszony do zajmowania się Leninem, konfrontacja ta okazała się niezwykle płodna i odegrała ważną rolę w rozwoju jego myśli. Mimo własnych zastrzeżeń, powołał do życia Lenina, który był już obecny w ówczesnych walkach i dzięki któremu można było rozważać główne problemy polityczne. Co więcej, Lenin dał Negriemu nową perspektywę czytania Marksa i nową wizję

6 Nie sugeruję oczywiście, że Sabel i Piore czytali prace Negriego, ale że interpretowali te same koniunkturalne warunki w obrębie tej samej kapitalistycznej rekonstrukcji. Sabel i Piore wskazują, że kapitał USA wciąż opłakuje koniec masowej produkcji i tkwi w kryzysie tożsamości. Nowym modelem, który wydaje im się najbardziej obiecujący, jest model włoski wraz z ówczesnym boomem ekonomicznym, napędzanym elastyczną produkcją względnie małych przedsiębiorstw. Powołując się na tezy operaizmu, można by argumentować, że Włochy rozwinęły ten nowy model wcześniej niż inne kraje, ponieważ w roku 1970 doszło tu do najintensywniejszych walk społecznych. Potrzeba jednak szczegółowych badań, aby podeprzeć takie rozumowanie. 
marksistowskiego wysiłku intelektualnego. Jednak nawet w swoim entuzjastycznym przyjęciu myśli leninowskiej, Negri wciąż nie wyzbył się pewnych zastrzeżeń - widać je pośrednio w polemikach z różnymi propozycjami leninizmu, które były obecne w ruchach oddolnych (zwłaszcza z tymi, które dotyczą awangardowości i organizacji militarnej). Znajdujemy się na grząskim gruncie. Postarajmy się więc być bardzo wrażliwi na zniuansowanie stanowiska Negriego, biorąc pod uwagę naciski ze strony praktyki i potrzeby, na które starał się odpowiedzieć7.

Jak już zauważyliśmy, podstawowe pytanie, które musi zadać sobie teoria, dotyczy podmiotowości - presja ze strony walki klasowej stawia je na pierwszym miejscu. Filozofia krytyczna nie potrafi sobie do końca poradzić z podmiotowościa rzeczywistej klasy robotniczej; krytyka kapitału nie daje się uzgodnić ze stanowiskiem klasy robotniczej, nie postrzega się w niej też proletariatu jako efektywnego podmiotu zmiany społecznej. Na przykładzie kontekstu włoskiego i myśli Negriego widać, że teoria krytyczna zamyka walkę klasowa przede wszystkim w formie obiektywnej, a rozwój społeczny pojmuje przez pryzmat dialektycznej dynamiki. Jednak wraz z wybuchem nowego cyklu walk klasa robotnicza domagała się rozpoznania jako bezpośredni i skuteczny podmiot zmiany społecznej. Negri stawia ważne pytanie, we właściwym sobie, politycznym kontekście: „Czym jest klasa robotnicza dziś, podczas tego specyficznego kryzysu, już nie jako obiekt wyzysku, ale podmiot sprawczy?” (Negri 1974, 105). Teoria krytyczna jest dobrym narzędziem, jeśli chodzi o rozpoznanie klasy robotniczej jako obiektu wyzysku czy raczej podmiotu konstytuowanego przez kompleksowe mechanizmy czy urządzenia (dispositifs) kapitalistycznej dominacji. Lenin pomaga Negriemu umieścić teorię podmiotowości w centralnym miejscu rozważań i uchwycić klasę robotniczą jako podmiot siły - podmiot, który zdolny jest zmieniać i przekształcać społeczeństwo.

Negri czyta leninowską teorię podmiotu przez pryzmat teorii organizacji klasy robotniczej - lub precyzyjniej, lokuje te rozważania na przecięciu analizy składu politycznego i teorii organizacji. Według niego, podmiotowość robotników i ich spontaniczne zachowania są centrum leninowskiej organizacji. Widać tu wyraźnie, że Lenin Negriego nie jest Leninem

7 Właśnie tutaj, w studiach Negriego nad Leninem, napotykamy na wszystkie historyczne trudności z interpretacją, o których wspominaliśmy wcześniej. Negri z pewnością stara się przechwycić głos bojowników i skierować ich analizy w stronę bardziej spójnych celów. Wyłuszczenie jego osobistych propozycji i oddzielenie ich od tych, które po prostu funkcjonowały w ruchu, wymagałoby szczegółowych badań historycznych. Będziemy próbowali obracać się w obrębie tych zagadnień najlepiej jak umiemy, skupiając się na polemikach Negriego i na kierunkach, w których zmierzała jego argumentacja. 
głównego nurtu. W jaki sposób pogodzić na przykład zachwyt Negriego nad podmiotowością robotniczą z tzw. „leninowską wattpliwością”, dotyczącą tego, że teoria organizacji nie jest wyznaczana bezpośrednio przez skład klasy robotniczej, ale jest raczej definiowana przez najsłabsze ogniwa w łańcuchu kapitalistycznej dominacji? (Negri 1974, 105). Tradycyjna doktryna leninowska lokuje źródło organizacji rewolucyjnej w krytyce ekonomii politycznej, a nie $\mathrm{w}$ teorii podmiotowości robotniczej. $\mathrm{Na}$ pierwszy rzut oka propozycja Negriego zdaje się sprzeczna z tą sławną „leninowską wątpliwością”. Zobaczymy jednak, że kiedy uwzględnimy szerszy kontekst myśli Lenina, sprzeczność ta okaże się pozorna. Krytyka ekonomii politycznej ma dla Lenina sens tylko wtedy, jeżeli funkcjonuje w obrębie teorii podmiotowości klasy robotniczej, jest tej teorii podporządkowana. Według Negriego, jeżeli nie wpiszemy myśli Lenina w analizę marksistowską i nie prześledzimy jej przekształceń w różnych okresach historyczno-politycznych, napotkamy mnóstwo tego typu dylematów. Innymi słowy, by docenić leninowską lekturę Marksa, musimy najpierw podążyć za marksistowską lekturą Lenina.

Negri proponuje podzielić rozwój teoretyczny Lenina na trzy etapy: 1) analiza politycznego składu klasy robotniczej (1890-1900); 2) organizacja partii (1900-10); i 3) destrukcja państwa (1910-17). W pierwszych dwóch okresach dostrzega dwie uzupełniające się wizje teorii podmiotu: pierwsza dotyczy jego spontanicznego działania, druga - receptywności. Dlatego też pierwsza prowadzi do podmiotowej organizacji robotników, a druga jest pomyślana obiektywnie. Badania dotyczące trzeciego etapu myśli leninowskiej (które są zakorzenione w rozważaniach nad podmiotem), musimy zostawić na później. Pierwszy okres, obejmujący takie dzieła jak Co to sq prayjaciele ludu? i Rozwój kapitalizmu w Rosji dotyczy przede wszystkim pojęcia „określonej formacji społecznej”. Koncepcja ta jest, według Negriego, kluczowa dla leninowskiego odczytania Kapitału. Marksistowska socjologia rozpoznaje najważniejsze struktury społeczne przez „zredukowanie ich do stosunków produkcji”, tym samym wyróżniając określaną formację społeczną (Negri 1976, 16). Nie możemy jednak dać się zwieść takiemu naturalistycznemu i obiektywistycznemu rozumieniu: ówczesna kultura polityczna była bowiem zdominowana przez taką terminologię (Negri 1976, 16-17). Ale w tym wczesnym okresie Lenin używa pojęcia „określona formacja społeczna” jako narzędzia, które pozwala badać skład klasy robotniczej i odsłaniać charakter podmiotu rewolucyjnego. Według Negriego, analizy Lenina dotyczące „określonej formacji społecznej” dają możliwość uchwycenia rzeczywistych 
warunków i działań klasy robotniczej, które pozwalają nam zlokalizować aktualną pozycję klasy robotniczej. Analiza społeczna ma w tym wypadku ukazać klasę robotniczą jako podmiot rewolucyjny. To podejście teoretyczne ma być kluczem do zrozumienia marksizmu Lenina: „Oryginalność leninowskiego podejścia do marksizmu objawia się w koncepcji klasy robotniczej (która opiera się na pojęciu określonej formacji społecznej i która staje się rzeczywista, jako siła w niemożliwej do zatrzymania tendencji)" (Negri 1976, 19). Lenin włącza więc klasę robotniczą do teorii na prawach dojrzałego podmiotu.

Taka interpretacja Lenina podparta jest analiza jego pism z lat 90. XIX wieku. Znajdziemy tam podstawowe rozpoznania leninowskiej teorii podmiotu (a więc i organizacji rewolucyjnej), które dotyczą spontaniczności klasy robotniczej: „pierwszą rzeczą, na którą zwracamy uwagę czytając te pisma, jest gloryfikacja spontanicznego działania, która nie ma w sobie nic z przypadkowości - jest ciąła i systematyczna” (Negri 1976, 20). Lenin zetkną się wówczas z wielką walecznością wysoko wykwalifikowanych robotników rosyjskich i zrozumiał polityczną wage tych spontanicznych walk ekonomicznych. Lenin wpisywał formację społeczną w skład i działania klasy robotniczej. I chociaż z punktu widzenia organizacji walki robotnicze mogą wydawać się niedojrzałe, zawsze wyrażają pewną polityczną intuicję, zawsze odnoszą się do pewnych stawek politycznych: „każda walka ekonomiczna jest walką polityczną” (Negri 1976, 20). Przez walki robotnicze zawsze przebija polityczna treść i w tym sensie agitacja ekonomiczna i spontaniczne wystapienia robotnicze są konieczną podstawą każdego proletariackiego programu politycznego. Zaciekła walka wysoko wykwalifikowanych pracowników i ich rozwinięta świadomość maja już w sobie cechy przyszłej, potężnej organizacji. Mimo ataków ze strony ortodoksyjnej tradycji leninowskiej, ekonomizm i spontaniczność są dla Negriego jednolitym punktem wyjścia w pismach Lenina z lat dziewięćdziesiątych XIX wieku. Spontaniczność jest bowiem poczattkiem wyłaniania się podmiotowości klasy robotniczej, a afirmacja spontaniczności mas jest pierwszym ruchem w stronę leninowskiej organizacji.

Jednak w następnej dekadzie (szczególnie w Co robić? z 1902 roku (Lenin 1985)), w teorii Lenina dokonuje się przeskok na bezpośrednio polityczny poziom. Mamy wyzbyć się „podporządkowania spontaniczności”. Lenin skupia się na walce i organizacji specyficznie politycznej, która wydarza się poza sferą starć ekonomicznych, poza spontanicznością mas. Propozycja politycznego przywództwa może wydawać się sprzeczna z duchem pism lat dziewięćdziesiątych XIX wieku. Dla Negriego jest ona jednak rozwinięciem pozycji, które Lenin zajmował wcześniej - a także ich teoretycznym dopełnieniem. Specyfika tego, 
co polityczne, określa bowiem drugi moment leninowskiej organizacji. „Dopiero pełne uświadomienie sobie, że walka ekonomiczna jest walką polityczną, pozwala przejść do kolejnego, fundamentalnego stwierdzenia: walka polityczna nie jest tylko walka ekonomiczną" (Negri 1976, 22). W pierwszym momencie, walki ekonomiczne robotników i spontaniczność mas stają się podstawą do pomyślenia organizacji rewolucyjnej. Moment przywództwa politycznego i autonomicznej organizacji politycznej jest więc tylko potwierdzeniem pierwszego. Innymi słowy, jeśli pierwszy z nich polega na afirmacji podmiotowości klasy robotników, to drugi moment jest afirmacją tej afirmacji. Wertykalna forma wyrażona w walkach ekonomicznych oraz hierarchiczne relacje między robotnikami formalizuja się w instytucji partyjnej - są podniesione do rangi siły. W jaki sposób interpretować więc atak na „podporządkowywanie się spontaniczności” wyrażony w Co robić?. Rozwiązaniem wydaje się pamiętanie o przechodzeniu od partykularności do uniwersalności mimo skupienia się na konkretnych, spontanicznych ruchach klasy robotniczej, musi przecież dokonać się skok jakościowy o charakterze politycznym. Negri zaznacza jednak, że skok ten musi wydarzać się w kontinuum zorganizowanego rozwoju. Intuicje obecne w spontaniczności mas muszą zostać zorganizowane, podniesione do poziomu świadomości: „organizacja jest spontanicznością, która przegląda się w sobie” (Negri 1976, 27). Kierunek wskazany przez świadome kierownictwo polityczne jest koniecznym dopełnieniem projektu zakorzenionego w zrachowaniach klasy robotniczej: „organizacja jest właściwie dowodem spontaniczności, jej ulepszeniem" (Negri 1976, 27). Przywództwo polityczne podnosi świadomość mas do rangi prawdy i daje klasie robotniczej wewnętrzną jedność"8. Negri utrzymuje, że partia leninowska odtwarza w sobie schemat fabryki: przetwarza surowiec robotniczej spontaniczności w spójną i subwersywną broń (Negri 1976, 43). Leninowska teoria organizacji jest więc jednocześnie krytyką dwóch stanowisk, które niejako wyznaczają jej granice. Z jednej strony, anarchosyndykalizmu, który rozpoznaje podmiotowość robotników w spontanicznych zachowaniach, ale odmawia jej specyficznie politycznej organizacji (Negri 1976, 43). Z drugiej strony, krytykuje się tu każda próbę stworzenia organizacji rewolucyjnej na innych podstawach niż spontaniczność mas.

\section{Określony skład klasowy: organizacja leninowska 2}

Paradoks leninowskiej teorii podmiotowości polega na idealnej tożsamości dwóch momentów organizacji. „Organizacja musi zawsze »ukazywać«, w marksowskim sensie, wolną aktywność klasy - w której możliwa jest jej prefiguracja” (Negri 1976, 60). Jaka jest logika tej

8 W leninowskiej koncepcji podmiotowości klasy robotniczej, którą przedstawia Negri, widać wyraźnie wątki heglowskie: kiedy przedstawia się partię jako wewnętrzny i samoświadomy podmiot. Kwestią dialektyki organizacji zajmiemy się w dalszych partiach tekstu. 
prefiguracjii? Co skłania Negriego i Lenina do myślenia, że spontaniczne ekspresje mas zawsze znajdują swoje rozwinięcie w programach politycznych przywódców? By odpowiedzieć na to pytanie, musimy przyjrzeć się leninowskiej koncepcji określonej formacji społecznej i obiektywnym warunkom, które poprzedzają „spontaniczność” podmiotu. W myśli Lenina obecna jest pewna obiektywna podstawa [teoretyczna], która funkcjonuje równolegle do spontanicznej możliwości organizacji i przechodzi od krytyki ekonomii politycznej przez analizę składu klasowego aż do teorii organizacji. Źródeł podmiotowości robotniczej należy szukać w specyfice stosunków produkcji, w zorganizowanej formie kapitalistycznego panowania. Uściślijmy więc, co rozumiemy przez „spontaniczność”, kiedy mówimy o wyłanianiu się podmiotowości robotniczej. Podmiotowość, która wyraża się w walkach ekonomicznych nie jest „spontaniczna” w tym sensie, że wyrasta z wolnej woli robotników; przeciwnie, walki są efektem pewnej określonej woli obecnej w materialnych warunkach pracy, w obrębie procesu produkcji. Spontaniczność odnosi się więc do tego, że wystąpienia robotnicze nie są determinowane przez zewnętrzną organizację - wyrastają bezpośrednio z warunków materialnych. Innymi słowy, leninowska afirmacja spontaniczności nie ma nic wspólnego z idealistyczna definicją podmiotu; przeciwnie, u Lenina „podmiot jest określany przez swój materialny skład: materialność walk, płac, osadzenia instytucjonalnego" (Negri 1976, 39). Podmiot definiuja konkretne warunki i relacje w obrębie jego pracy.

Lenin przedstawia obiektywne warunki, które poprzedzają formowanie się podmiotowości robotniczej, kiedy dokonuje teoretycznego przejścia od krytyki ekonomii politycznej do analizy składu klasowego. Uważa, że pytanie o organizację rewolucyjną odnosi się do fenomenologii klasy robotniczej. W specyficznym kontekście przedrewolucyjnej Rosji dostrzega przemysłową klasę robotnicza, która w obrębie procesu pracy jest zorganizowana hierarchicznie - bardziej wyszkoleni robotnicy przewodzą nisko wykwalifikowanym, zachowują jednak do nich szacunek. Wyspecjalizowany charakter wykonywanych zadań oraz dosyć sztywne podziały wewnattrz fabryki (typowe dla Rosji tamtego okresu), zapewniaja warunki do wykształcenia się „wykwalifikowanego robotnika” jako paradygmatu podmiotowości robotniczej. Propozycja, aby postrzegać wysoko wykwalifikowanego robotnika jako paradygmatyczny podmiot jest abstrakcyjna, ale (używając pojęć Marksowskich), jest to abstrakcja określona, tzn. taki rodzaj pojęcia, które nie jest oparte na idealistycznej spekulacji, ale na rozpoznaniu rzeczywistych tendencji w konkretnym, materialnym świecie - w tym przypadku w obrębie składu klasowego. Podmiotowość robotnika paradygmatycznego jest więc określona przez specyficzne stosunki produkcji, 
a skład tej podmiotowości wyznacza model organizacji rewolucyjnej. W tym sensie w zorganizowaniu procesu pracy następuje prefiguracja organizacji robotników. Aby bazować na określonej podmiotowości robotniczej, partia powinna podążać za hierarchicznym zorganizowaniem produkcji kapitalistycznej w Rosji i odtworzyć takie same relacje pomiędzy awangarda a masami z fabryk. Partia leninowska ,jest więc partią cały czas skupiona na odzyskiwaniu i łączeniu różnych serii, warstw, form pracy, form przetrwania, dochodu i walki” (Negri 1976, 58). Partia awangardowa powinna być „zewnętrzna” i reprezentować klasę robotniczą w takim stopniu, w jakim wykwalifikowany robotnik jest oderwany od masy robotników w sferze produkcji (Negri 1976, 29). Siła i jednoczesne ograniczenie leninowskiej teorii organizacji tkwi właśnie w tym bliskim związku z określonymi stosunkami produkcji. Jako organizacja robotnicza, partia leninowska jest w przedrewolucyjnej Rosji skuteczna, ponieważ odzyskuje sposób organizacji nierozerwalnie związany z ówczesnymi procesami w obrębie produkcji przemysłowej. Stąd jej ograniczenie - forma partii bolszewickiej jest efektywna tylko do momentu, do którego utrzymuje się pewien specyficzny sposób organizacji produkcji.

\section{Aktualność Lenina: marksizm projektujący}

Najważniejszą lekcją Lenina, czy może marksistowskiego odczytania Lenina przez Negriego, jest „potrzeba odniesienia dyskusji i pytań o organizację z powrotem do realnej materialności aktualnych ruchów klasowych" (Negri 1988, 112). Paradoksalnie, afirmacja Leninowskiej teorii organizacji służy Negriemu, by pokazać, w jaki sposób historycznie specyficzna forma leninowskiej organizacji nie odpowiada już współczesnym przejawom podmiotowości robotniczej i obecnym stosunkom produkcji. Dyskurs leninowski odpowiadałby naszym potrzebom tylko pod warunkiem, że polityczny skład klasy robotniczej z jego czasów byłby podobny do tego, z którym mierzymy się my; rozbieżności widać jednak gołym okiem (Negri 1976, 33). Kiedy spojrzymy na potrzeby i zachowania klasy robotniczej we Włoszech, stanie się jasne, że spontaniczne wyrazy podmiotowości nie przybierały formy wertykalnej - zamiast wyselekcjonowanej świadomej elity mieliśmy do czynienia raczej z szerokim, horyzontalnym działaniem. Dekady walki partyzanckich zrobiły swoje - często mówiło się, że robotnicy internalizuja strategie walk i wyrażają się w mnogości autonomicznych form, z dala od elit robotniczych i poza „oficjalnymi” ruchami robotniczymi. Szczegółowe studia Romano Alquatiego nad samowolnymi strajkami w fabrykach Fiata daja doskonały obraz masowych zachowań robotników (Alquati 1975). Widać też wyraźnie, że zbiorowe wystapienia robotnicze we Włoszech lat sześćdziesiątych i siedemdziesiątych XX wieku były zupełnie 
inne od ograniczonych przejawów sprzeciwu, z którymi mieliśmy do czynienia pośród elit robotników rosyjskich z początku wieku. Te pierwsze przybrały charakter spontaniczny, bardziej horyzontalny niż wertykalny. Materialne ruchy klasy robotniczej potrzebowały więc zupełnie innej podmiotowości.

Do podobnych konkluzji dochodzimy, gdy przyglądamy się leninowskiej „obiektywnej” drodze do organizacji. W teoretycznym przejściu między krytyką ekonomii politycznej a składem klasowym analizuje się warunki, które umożliwiają formowanie się podmiotowości robotniczej. Jak widzieliśmy, wyspecjalizowana produkcja przemysłowa w Rosji dała podstawy do wykształcenia się „wykwalifikowanego robotnika” jako paradygmatu podmiotowości robotniczej. Negri jednak bardzo szczegółowo pokazał, że reakcja kapitału na Rewolucję Październikową polegała na ograniczaniu produkcji warunki dla rozwoju „robotnika wykwalifikowanego” zostały zniszczone. Umasowienie produkcji i obniżanie poziomu kwalifikacji siły roboczej doprowadziło do zniszczenia hierarchii wśród robotników. Kapitał spłaszczył więc starą relację między awangardą i masami, która wcześniej charakteryzowała organizacje robotnicze. Podstawa, dzięki której awangarda mogła być postrzegana jako zewnętrzna i reprezentatywna w stosunku do klasy, przestała istnieć.

Negri postrzega tę historyczną zmianę (która oddziela nas od czasów Lenina), w kategoriach marksowskich: jako przejście od formalnej do realnej subsumcji pod kapitał. W fazie subsumcji formalnej mamy do czynienia z pewnym pęknięciem między społeczną produkcją a kapitalizmem: niektóre autonomiczne, przedkapitalistyczne formy produkcji i kooperacji społecznej pozostają zewnętrzne wobec kapitału i sa wyłącznie formalnie podporządkowywane globalnej machinie kapitalistycznego panowania. Jednak w procesie realnej subsumcji siła robocza i kapitalistyczne stosunki produkcji zostają rozszerzone horyzontalnie na całe społeczeństwo. Praca i produkcją są określeniami czysto społecznymi, a co za tym idzie, „społeczna fabryka” jest zupełnie rozproszona. Krótko mówiąc, realna subsumcja przejawia się w bezpośrednim podporządkowaniu społeczeństwa kapitałowi. Negri zwraca uwage, że podczas gdy Marks rozpoznawał przechodzenie od formalnej do realnej subsumcji jako tendencję w obrębie kapitalizmu, dziś stała się ona rzeczywista. W następnych latach Negri zrobi duży pożytek z tego marksowskiego rozróżnienia, ale w tym momencie, na potrzeby naszych ograniczonych rozważań, argumenty brzmiałyby dosyć prosto: Lenin poprawnie rozpoznał pęknięcie, jakie w warunkach subsumcji formalnej 
zachodzi między partykularnością walk ekonomicznych a powszechnością walk politycznych - ta luka miała być wypełniona przez organizację partyjna. Jednak dziś znikły podstawowe założenia, na których opierały się rozpoznania Lenina. „Przejście od szczegółowości do powszechności, od walk ekonomicznych do politycznych [...] traci znaczenie i wagę, jaka nadała mu myśl leninowska. [...] Bowiem w naszych czasach walka ekonomiczna i polityczna jest kompletnie identyczna (Negri 1976, 34-5). Podstawowe przejścia Leninowskiej organizacji (od szczegółu do ogółu, od tego, co ekonomiczne do tego, co polityczne), nie przystają już do naszej rzeczywistości. Na tych rozróżnieniach opierała się z kolei propozycja Lenina dotycząca Partii, znajdującej się na zewnątrz klasy robotniczej. Jednak dziś, w warunkach realnej subsumcji, kiedy rozróżnienia te już się wyczerpały, nie ma podstaw dla politycznej organizacji zewnętrznej wobec klas.

Jaki jest więc cel tak szerokich i szczegółowych studiów nad Leninem, skoro Negri dochodzi do wniosku, że jego rozpoznania są całkowicie przestarzałe i nieprzystające do bieżącej sytuacji klasowej? Do jakiego stopnia Negri w ogóle uznaje się za leninistę? „Nie istnieją fetysze, dotyczy to także Lenina; który wymaga poświęceń” (Negri 1976, 68). Nie potrzeba nam kultu Lenina. Nie potrzebujemy potwierdzania wierności abstrakcyjnym modelom, które stworzył; z Lenina powinniśmy raczej przyswoić sobie pewien projekt: czytania rzeczywistego, bieżącego składu klasowego robotników, a następnie interpretowania ich podmiotowości, ich potrzeb, zorganizowanej ekspresji. Najbardziej innowacyjnym aspektem myśli Lenina jest jego metodologia mas, teoria masowej inteligencji; zdolność do rozpuszczania teorii w praktyce mas i krystalizowaniu jej ponownie w jednym, centralnym ujęciu. „A więc leninizm jako metoda, jako metoda masowa, jako masowa praktyka [...] w tym sensie, w jakim leninizm wiąże losy Rewolucji ze zdolnością mas do natychmiastowej przemiany w podmiot. W takim nowym rozumieniu zachowana zostaje kompleksowość procesu - objawia się ona w przejściowym pojęciu walki rewolucyjnej jako sztuki" (Negri 1976, 68). Leninizm jest sztuka, o ile w praktykach mas potrafi uchwycić podmiot rewolucyjny. W rękach Negriego leninizm staje się propozycją reorientacji marksistowskiego wysiłku, włączeniem i podporządkowaniem krytyki kapitału rewolucyjnemu projektowi klasy robotniczej - rozpuszczeniem się i ponownym ustanowieniem teorii $\mathrm{w}$ obrębie praktyki mas. Na tym właśnie polega aktualność myśli Lenina. 


\section{Awangarda masowa i dwuznaczność centralności robotniczego punktu widzenia}

Na płaszczyźnie teoretycznej Negri stara się ożywić Leninowską koncepcję rewolucyjnego podmiotu, uzupełniając ją o bieżący kontekst społeczno-polityczny. Jeśli przyjrzymy się, jak koncepcje te funkcjonowały w ówczesnych warunkach włoskich, dostrzeżemy w myśli Negriego istotną rozbieżność - niektóre propozycje Lenina ostały się, chociaż wydawały się być już dawno odrzucone. W bliskich sobie kręgach politycznych Negri opowiada się na przykład za tym, by namysł teoretyczny nad podmiotem rewolucyjnym koncentrował się na zwykłym robotniku fabrycznym, a co za tym idzie, na organizacji awangardowej Partii, zdolnej prowadzić ruch. Musimy być jednak bardzo ostrożni, gdy pochylamy się nad takimi stwierdzeniami - są one mocno związane z ówczesnymi zmiennymi uwarunkowaniami, tak charakterystycznymi dla sytuacji włoskiej z tego okresu. Dlatego też, mając cały czas na uwadze, jak burzliwa była wtedy scena polityczna, postaramy się uporządkować te praktyczne propozycje Negriego, aby rozjaśnić rozwój jego myśli na tym etapie.

Negri był jednym z założycieli Potere operaio (Siły robotniczej), organizacji politycznej która istniała w latach 1969-73. Jej status był z grubsza nieokreślony, ale w jednym z ważniejszych i bardziej problematycznych tekstów z tego okresu Negri przedstawia propozycję programu, w jaki sposób przekształcić Potere operaio w partię rewolucyjną (Partio operaio contro il lavoro - Partia robotnicza przeciwko pracy; tekst krążył wśród członków ruchu w różnych formach). Jako partia, Potere operaio miałaby być punktem skupienia czy właśnie awangardą dla różnorodnych walk, a przez to torować drogę ku Rewolucji. Mając na uwadze ramy teoretyczne, w których się poruszamy, najbardziej problematyczna wydaje się koncepcja, która podkreśla znaczenie podmiotu rewolucyjnego, zogniskowanego wokól robotników fabrycznych. Robotnik masowy jest bowiem przedstawiany jako paradygmat podmiotowości, jako awangarda całej klasy robotniczej. Pojęcie partii awangardowej ostaje się więc w refleksji Negriego, mimo iż wiedzieliśmy, że warunki jej istnienia zostały podważone. Negri potrafi dosyć spójnie wyjaśnić tę paradoksalną sytuację, ale by zrozumieć jego argumenty, musimy osadzić je w kontekście ówczesnej, szybko zmieniającej się sytuacji społecznej i ostrej przemocy politycznej. Kiedy już dobrze usytuujemy argumentację Negriego, zobaczymy, że apel o jedność robotniczą miał być głosem umiarkowania - mediującym między radykalizmami obecnymi w ówczesnych ruchach robotniczych. 
Nie jest łatwo osadzić postulaty Negriego dotyczące partii awangardowej w obrębie jego rozważań teoretycznych. Być może najprościej odwołać się do schematu periodyzacji stosunków pracy, który zaproponował. Zgodnie z nią, kapitalistyczna produkcja w końcu XIX wieku, w swojej głównej tendencji, dążyła do wykształcenia jak najbardziej wyspecjalizowanego modelu fabryki. Wraz ze zmianami warunków w obrębie stosunków produkcji rozwijał się paradygmat podmiotowości robotniczej: wykwalifikowany robotnik. Aż do momentu, w którym, ze względu na swoją niezależność, okazał się on zagrożeniem dla istnienia kapitału - zorganizowal się bowiem w profesjonalną, awangardową partię. Następnie transformacja kapitalistyczna w produkcję masową zniszczyła warunki rozwoju wykwalifikowanego robotnika i dała podwaliny pod nową podmiotowość robotniczą robotnika masowego. Teoretyczny schemat daje się więc logicznie uzupełnić o partię masowej awangardy jako formę organizacji adekwatną dla masowego podmiotu robotniczego.

\begin{tabular}{|lr|c|c|}
\hline \multicolumn{1}{|c|}{$\begin{array}{c}\text { dominująca struktura } \\
\text { kapitalistycznej produkcji }\end{array}$} & $\begin{array}{c}\text { paradygmat podmiotowości } \\
\text { klasowej }\end{array}$ & adekwatna organizacja \\
\hline $\begin{array}{l}\text { wyspecjalizowana r produkcja } \\
\text { przemysłowa }\end{array}$ & robotnik wykwalifikowany \\
masowa & produkcja & partia profesjonalnej awangardy \\
przemysłowa & & partia masowej awangardowy \\
\hline
\end{tabular}

Dlatego też, gdy Negri stwierdza, że „powrót do teorii partii, która łatwo powtarza rozpoznania Lenina, jest niemożliwy (mając na uwadze obecny skład klasowy)” (Negri 1976, 63), nie odrzuca on aktualności koncepcji partii awangardowej w ogóle, ale argumentuje raczej za jej „masowym”, a nie „kadrowym” charakterem. „W rzeczywistości koncept awangardy zostaje zmodyfikowany, przekształcony w »awangardę masową" (Negri 1976, 61). Wszystkie niejednoznaczności streszczają się w tym paradoksalnym pojęciu. „Masowość” awangardy zdaje się uniemożliwiać jakikolwiek dystans czy zewnętrzność polityczną elity wobec mas. Krytykując Lenina Negri dowodzi, że rozróżnienie na to, co ekonomiczne i to, co polityczne, jest już nieadekwatne w obliczu nowej sytuacji klasowej. Dlatego też organizacja polityczna winna dążyć do jedności robotniczej nie z zewnątrz, jak chciał Lenin, ale z oddolnych, masowych pozycji: „Ten proces unifikacji nie może zostać przeprowadzony z góry - tylko od dołu, tylko z »wewnątrz«" (Negri 1974, 130). Organizacja rewolucyjna 
powinna być organizacją masowa, w tym sensie, w jakim wyrasta z klasy. Ze względu na siłę tej masowej podmiotowości, klasa robotnicza odrzuca wszelką formę reprezentacji czy zewnętrznego przywództwa i określa samą siebie jako bezpośredni podmiot siły. „Klasa może scedować władzę tylko na samą siebie” (Negri 1974, 147). Wydaje się jednak, że jeden człon tego pojęcia („masowość”) stoi w sprzeczności, a przynajmniej pozostaje problematyczny, w stosunku do drugiego (,awangardowość”). Organizacja pozostaje bowiem zjednoczona i skupiona wokół awangardy, która pozostaje jednak w jakimś stopniu zewnętrzna wobec mas. Na płaszczyźnie teoretycznej dystynkcja rozgrywa się w obrębie pracy produkcyjnej: robotnikom masowym $z$ wielkich fabryk nadaje się rolę politycznej awangardy, ponieważ stanowią oni jądro kapitalistycznej produkcji. Ze względu na tę polityczną range i relatywną autonomię, awangarda robotników fabrycznych dzierży uprzywilejowaną hegemonię nad resztą klasy robotniczej, a przez to także nad całym społeczeństwem. W tym sensie Negri na nowo stawia kwestię rewolucyjnej centralizacji i politycznej potrzeby Partii. W paradoksalnym stylu proponuje, aby Partia ta była jednocześnie ,z wnętrza” jak i „z zewnątrz” klasy.

Widzimy tu jednak powrót do starych, leninowskich rozróżnień na to, co ekonomiczne i to, co polityczne. „Koncepcja partii opartej na masowych awangardach jest koncepcja unifikująca walki płacowe i rewolucyjną walkę o władzę" (Negri 1974, 135). Masowe starcia o charakterze ekonomicznym (o wyższe pensje, przeciwko pracy) i awangardowa walka polityczna (o władzę), musza być postrzegane jako jednocześnie rozłączne i połączone. Analiza tych dwóch typów walk doskonale koresponduje ze strategiami organizacyjnymi. Komunistyczna tradycja oporu antyfaszystowskiego (sięgająca drugiej wojny światowej) zakłada organizowanie się na dwóch poziomach: masowym i elitarnym (niejawnym). Propozycja „masowej awangardy” jest próba zachowania sily, jaka daje ta strategia, ale jednocześnie stara się przepracować jej dualizm w syntetyczna jedność. Jednym, dialektycznym ruchem Negri próbuje rozwiązać ten teoretyczny dylemat, zarówno na poziomie analitycznym, jak i organizacyjnym. Oba rodzaje walk są więc dialektycznie zjednoczone w masowej partii awangardowej - przejście od wielości walk ekonomicznych do jednolitego podmiotu walki politycznej jest przejściem od ilości do jakości. „Tylko Marksowskie wykorzystanie materialistycznej dialektyki pozwala nam pogłębić i rozjaśnić pojęcie masowej awangardy, a więc także i koncepcję partii robotniczej występującej przeciwko pracy" (Negri 1974, 136). Jednak nawet zwrot do dialektyki nie pozwala Negriemu na przekonujące rozwiązanie tego problemu. „Awangarda masowa” wciąż pozostaje paradoksem. Niemniej jednak cel Negriego wydaje się jasno określony: chce on wpaść na trop 
takiej społecznej syntezy, która jest w stanie stworzyć spójny podmiot rewolucyjny, na tyle silny, aby sprostać wymogom bieżącej walki klasowej.

\section{Przemoc polityczna i terroryzm}

Ten teoretyczny zamęt rozjaśnimy tylko, jeśli zdamy sobie sprawę z nacisków, jakim podlegał w owym czasie Negri oraz z tego, że jako intelektualista starał się odgrywać rolę mediatora. W latach siedemdziesiątych XX wieku, wśród uczestników ruchów oddolnych panowało powszechne przekonanie, że nadchodzi czas ostatecznego obalenia państwa włoskiego, czas wojny domowej, czas przewrotu. Przemoc polityczna nie była już sprawą dyskusyjna; we Włoszech należała do codzienności politycznej, przywykły do niej obie strony konfliktu. Giorgio Bocca, jeden z dziennikarzy śledzących karierę Negriego, próbował opisać dyskurs walki zbrojnej tego burzliwego okresu. „Byłaby to operacja ahistoryczna, zadanie właściwie formalne, gdybyśmy wyrwali przemoc i wywrotowy charakter Potere operaio z kontekstu tamtych czasów - sytuacji wewnętrznej i międzynarodowej. [..] Jako historycy musimy pamiętać, że w latach 1969-74 przemoc polityczna była zjawiskiem szeroko tolerowanym, można by nawet powiedzieć: prawie normalnym” (Bocca 1980: 70). Przemoc była więc zastanym elementem sceny politycznej. Z punktu widzenia robotników wyglądało to następująco: państwo przyciśnięte do muru przez siłę robotniczą, by zachować sterowność, odwoływało się do przemocy jako jedynej, skutecznej metody.

Najbardziej znanymi przykładami są tu starcia z roku 1969 w Turynie (na Corso Traiano) i w Battipaglii (Negri et al. 1983, 233). Zgodnie z powyższym sposobem myślenia walka z kapitalistycznym panowaniem musiała przyjąć jakąs formę działań zbrojnych. Negri nie jest więc wcale taki radykalny, kiedy mówi: „Dziś jedynie walka zbrojna przemawia za komunizmem" (Negri 1974, 136). Bądźmy jednak bardzo ostrożni, wchodzimy bowiem teraz na niezwykle problematyczny i kontrowersyjny teren - pamiętajmy więc, że celem naszych rozważaniach jest tylko objaśnienie pewnych praktycznych i teoretycznych pozycji, które zajmował Negri.

Jeśli chodzi o przemoc polityczną, stanowisko Negriego kształtują dwie ważne polemiki: z jednej strony ta z „populistami” czy „narodnikami”, z drugiej strony ta, którą prowadzi z „subiektywistami”. Zarzut wobec populistów polega na tym, że w mówiąc o wojnie domowej, za mały nacisk kładą na potrzebę centralnej organizacji. Negri argumentuje za tym w dwojaki sposób. Po pierwsze, kiedy dialog polityczny zostaje 
zredukowany do przemocy, klasa robotnicza musi umieć się bronić, musi wytoczyć siły równe siłom państwowym; partia musi stać się „odbiciem, zwierciadłem” panowania kapitalistycznego i siły państwa (Negri 1974, 142). Jeżeli proletariat chce podjąć ofensywę na tym odcinku (jako ruch paramilitarny), potrzebuje scentralizowanego i spójnego kierownictwa. Każdy akt przemocy należy bowiem wpisywać we wspólny projekt poszerzania celów i zdolności organizacyjnych robotników (Negri 1974, 152). To z kolei prowadzi do drugiego argumentu przemawiającego za scentralizowanym kierownictwem: w sytuacji tak rozpowszechnionej przemocy, brak organizacji prowadzi do bezsensownych strat - zarówno po stronie robotników, jak i po stronie społeczeństwa w ogóle. Wielu intelektualistów związanych z ruchem robotniczym - w tym Negri - uważało, że ich rola jest właśnie bycie pewnego rodzaju pośredniczącym filtrem, który mógłby chronić przed bezcelową przemocą i równie bezsensownymi ekscesami.

Druga polemiką, którą toczy Negri, jest ta przeciwko „subiektywistom” czy „woluntarystom”. Nie należy ich krytykować za samo użycie siły, ale raczej za „nieumiejętność wejścia w organičnna relacje między podmiotowościa siły robotników a subiektywnościa każdego użycia przemocy" (Negri 1974, 139). Subiektywiści proponują bowiem bezpośrednie akcje przeciwko państwu i kapitałowi pod przywództwem zbrojnej awangardy, zewnętrznej wobec klasy robotniczej, ale działającej w jej imieniu. Pamiętajmy, że była to bez watepienia ważna frakcja w ruchu, której nie można było zignorować. W dużym stopniu opierała się na antyfaszystowskiej tradycji partyzanckich kombatantów ${ }^{9}$. Jednak teoretyczna analiza tego, jak ówcześnie działał kapitalizm, wprowadza jeszcze element taktyczny, którego stawki są niezmiernie wysokie. „Wśród kadr bojowników ruchu są tacy, którzy z wielkim przekonaniem utrzymują tezę o »faszyzacii państwa" "(Negri 1974, 154). Jeśli państwo przyjęło formę faszystowska, relatywnie autonomiczną wobec kapitału argumentowali niektórzy - ruch robotniczy powinien walczyć wykorzystując tradycyjne, antyfaszystowskie metody: używając uzbrojonych brygad niezależnych od klasy. Negri kontrargumentuje w oparciu o swoje wcześniejsze krytyki prawnego i ekonomicznego funkcjonowania kapitalizmu. Współczesne państwo - pisze - nie ma na celu złamania klasy

9 Najlepszym przykładem grup, które były aktywne w tym okresie, są GAP, Gruppi di Azione Partigiano (Partyzanckie Grupy Akcji). Nazwę swą wzięły od jednej z bojówek partyzantów, które walczyły z faszystami podczas drugiej wojny światowej. Grupa była mała, ale bardzo sławna, po części ze względu na aktywną działalność Giacomo Feltrinelliego, znanego i bogatego wydawcy. Feltrinelli zginął podczas próby podłożenia bomby. 
robotniczej, jak chcieli faszyści; zależy mu raczej na jej włączeniu i wykorzystaniu w procesie rozwoju (Negri 1974, 150). Dlatego też, mając na uwadze naturę przeciwnika klasy robotniczej, kierunek polityczny i użycie siły musi zawsze organicznie wyrastać z masowej podmiotowości klasowej. „Nie ma dziś miejsca [...] na oswobadzającą ofiarę awangardy [...]. W naszej organizacji nie ma też miejsca na przestarzałe formy woluntaryzmu; mówimy z wnętrza ruchu masowego, rozwijamy naukowe (a więc i praktyczne) rozumienie jego składu i jego pragnień" (Negri 1988, 141-142). W kontekście wojny domowej Negri nie potępia przemocy ze strony mas. Jednak samo użycie siły nie może być nigdy fetyszyzowane; musi być zawsze podporządkowane rozwojowi ruchu (Negri et al. 1983, 233). Wszelkie nadużycia wynikają bowiem z tego, że zbrojny ruch odrywa się od rzeczywistych posunięć mas i aktualnego składu klasy robotniczej. Subiektywiści - twierdzi Negri - proponuja redukcjonistyczne odczytanie faszyzmu państwa, które prowadzi do mniejszościowych aktów przemocy, praktykowanych w oderwaniu od kontekstu masowego: „kiedy jakakolwiek praktyka jest wymuszana z zewnątrz, rezultat okazuje się nieuchronnie terrorystyczny" (Negri $1974,100)$.

Warto podkreślić, że stanowisko Negriego w sprawie przemocy okaże się jeszcze bardziej spójne, kiedy odniesiemy je do jego teorii podmiotu. Awangarda masowa jest bowiem podmiotem o dwóch twarzach: jeden jej aspekt to rozproszone i pluralistyczne zachowanie mas, ugruntowane $\mathrm{w}$ odrzuceniu relacji pracy i marzeniu o wolności; druga twarzą jest spójne przywództwo awangardy robotników fabrycznych, które konstytuuje lustrzany antagonizm z państwem. W kontekście wojny domowej i konfrontacji z państwową przemoca, pierwszy aspekt reprezentowałby defetystyczną pozycję narodników; drugi, pozostawiony sam sobie, oderwany od mas, może prowadzić jedynie do terroryzmu. Tylko synteza siły mas i kierownictwa umożliwia - twierdzi Negri - powstanie adekwatnego podmiotu rewolucyjnego ${ }^{10}$.

\section{Przypis - Lenin i Nietzsche: cięcie podmiotowe i cięcie ontologiczne}

Intensywność walk społecznych we Włoszech sprawiła, że pytanie o podmiotowość znalazło się na pierwszym miejscu pośród zagadnień teoretycznych. W tym kontekście kwestia

$10 \mathrm{~W}$ tekście Partito operiao contro il lavoro (Partia robotnicza przeciwko pracy) Negri proponuje utworzenie basi rosse (czerwonych posterunków) i brigate rosse (czerwonych brygad), które miałyby być częścią wspólnego planu zadań dla proletariatu. Można sobie wyobrazić, że był to wystarczająco „kryminalny” dowód w późniejszym postępowaniu przeciwko niemu. Warto jednak pamiętać, że tekst ten ukazał się jeszcze przed utworzeniem historycznych Czerwonych Brygad i że w tamtym okresie wyrażenie to było używane przez różnych aktywistów ruchu w rozmaitych kontekstach. 
organizacji politycznej wydaje się być tylko bardziej praktycznym przejawem teorii podmiotu. Negri w najwyższym stopniu stara się więc sprostać wyzwaniu postawionemu przez ruchy społeczne; chce ująć ten wyłaniający się podmiot w kluczowym momencie jego siły i włączyć go do namysłu teoretycznego. Musimy rozpoznać klasę pracująca - mówi Negri - nie tylko jako obiekt wyzysku, ale jako podmiot siły; nie tylko jako bierny przedmiot skonstruowany na przecięciu urządzeń kapitalistycznej dominacji, ale także jako aktywny podmiot, który konstytuuje sam siebie - na bazie swych własnych marzeń i pragnień projektuje nowe społeczeństwo. Walki społeczne, wraz z ich podmiotowa siła, wywarły na Negriego ogromny wpływ. Można powiedzieć, że doprowadziły też do pewnego teoretycznego zerwania. Uniwersyteckie podejście teorii krytycznej, domagającej się „obiektywnego” odczytywania ruchów społecznych i historycznych zostało od teraz podporządkowane żądaniom klasy robotniczej - jej projektowi jako podmiotu.

Negri nie postrzega tej reorientacji, inwersji w podejściu do krytycznego marksizmu, jako odejścia od Marksa. Jest to dla niego raczej pogłębienie problematyki marksistowskiej i próba takiego myślenia, w którym wyłanianie się podmiotowości klasy robotniczej jest (szczególnie dla dojrzałego Marksa) kwestią najważniejszą. Operaizm jest być może najlepszym nurtem w marksizmie, jeśli chodzi o punkt wyjścia dla powyższej reorientacji krytykę [kapitału] osadza bowiem zawsze w aktualnym położeniu klasy robotniczej. Ulubionym Marksem operaistów jest ten z roku 1848; ale także Marks Komuny Paryskiej, teoretyzujący w wirze entuzjazmu, niesiony siłą i nadzieja proletariatu. Jednak dla Negriego przejście do nowych odczytań Marksa dokonuje się za sprawą Lenina. Interpretując go i krytykując, Negri wywyższa klasę robotniczą do roli ważnego podmiotu społecznego, który - u swoich podstaw - zakorzeniony jest w materialnych warunkach pracy; w konkretnych, podmiotowych ekspresjach mas. Podmiot ten, w swoim szczytowym momencie, dąży do osiagnięcia siły, doskonaląc swoje możliwości wyrazu i samoorganizacji.

Niektórzy sugerowali, że ten powrót do zajmowania się Marksem i Leninem przebiega w myśli włoskiej równolegle do rozwinięć teoretycznych Louisa Althussera (Piotte 1986, 17). To podobieństwo prima facie, „powrót do rewolucyjnego Marksa i Lenina”, po dokładniejszej analizie okazuje się złudne. Odsłaniają się bowiem podstawowe różnice między Negrim a głównymi nurtami współczesnego, zachodniego marksizmu - zwłaszcza jeśli chodzi o kwestię podmiotu. Konfrontację Negriego z Althusserem widać najlepiej, gdy porównamy ich stanowiska dotyczące rozwoju myśli Marksa; propozycja Althussera, wedle której 
najważniejszym punktem zwrotnym w Marksowskiej ewolucji jest przejście od młodzieńczego humanizmu do strukturalistycznej, dojrzałej fazy krytyki klasycznych ekonomistów - propozycja ta jest dla Negriego nie do przyjęcia.

Jeśli chcemy mówić o „cięciu epistemologicznym” u Marksa, trzeba przez to rozumieć moment, od którego na definicję struktury nie składa się już dłużej tylko relacja między kryzysami kapitalistycznymi a ruchami klasy robotniczej. Analiza wyzwala się wtedy z aktualnych warunków funkcjonowania, by przekształcić się w program; bieżące relacje sił stają się propozycjami organizacyjnymi. Cięcie epistemologicæ̨ne to narodziny organizacji (Negri 1974, 103n).

Negri wskazuje, że Althusser, wpisując Marksa w strukturalistyczny horyzont krytyki ekonomii politycznej, osłabia siłę analiz. Odrywa je od rewolucyjnego, podmiotowego osadzenia w organizacji klasy robotniczej. Strukturalna krytyka ekonomii politycznej porusza się w sterylnej, niezamieszkanej przestrzeni - i jest to bardzo dalekie od Marksa:

Albowiem sam Marks nigdy nie postuluje „procesu bez podmiotu”. Przeciwnie. Ewolucja jego myśli zawsze uważnie podąża za rzeczywistością - rzeczywistością organizacji podmiotu rewolucyjnego. Prawdziwym rezultatem krytyki ekonomii politycznej jest zawsze to podmiotowe osadzenie (Negri 1974, 103n).

Podmiot rewolucyjny jest zarówno teoretycznym efektem, jak i siłą napędzająca Marksowskie wysiłki.

Przyjmijmy, że prawdą jest - jak to ustaliliśmy wcześniej - że to ze względu na eksplozję działań włoskiej klasy robotniczej po 1968 roku Negri jest niejako „zmuszony” uznać kluczową rolę podmiotu w teorii Marksa. Ale w takim razie równie ważne okazuje się to, że Negri nie mógłby tego zrobić bez wsparcia teoretycznego, jakie dały mu Leninowskie odczytania Marksa. To Lenin odkrył bowiem, jak osadzić podmiot rewolucyjny (wraz z jego materialnymi żądaniami i konkretnymi praktykami) w samym sercu teorii. I właśnie ten intelektualny związek z Leninem pokazuje jeszcze mocniej, jak bardzo oddalone są od siebie drogi Negriego i Althussera. Punktem wyjścia dla tego drugiego jest dyskusja z akademikami, którzy mieliby nie doceniać i nigdy do końca nie uznać Lenina jako filozofa (Althusser 1971: 22-70). Mamy więc zająć się nie Leninowską praktyką per se, ale raczej sposobem, w jaki praktyka była teoretyzowana, a co za tym idzie, mamy skupiać się na odnawianiu teorii rewolucji (czy raczej, rewolucji w teorii). Właśnie tak Althusser odczytuje sławne motto 
Lenina: „bez teorii nie ma rewolucyjnej praktyki”: zagadnienia rewolucyjnej praktyki muszą być oparte na sferze teoretycznej lub jej podporządkowane. W jego ujęciu geniuszem Lenina było wprowadzenie walki klasowej do filozofii. Tym samym jednak, to Althusser stara się wprowadzić Lenina do galerii uniwersyteckich sław. Negri z kolei chce wyprowadzić Lenina z Akademii i wsadzić go w sam środek fabryki - nie chce włączać walk klasowych do filozofii, tylko praktykować je. Jego ulubione motto kolejny raz wskazuje na dystans w stosunku do Althussera: „o wiele bardziej interesująco i pożytecznie jest robić rewolucję niż o niej pisać” (z posłowia do Państwa i rewolucji, Negri 1976, 129; 152). W rozumieniu Negriego nie da się oderwać Lenina od jego konkretnej praktyki. Studia nad Leninem, połączone z wybuchem walk społecznych, wyznaczają pewne zerwanie, punkt zwrotny w myśli Negriego: jest to właśnie cięcie podmiotowe. Silny podmiot staje się w jego pracy teoretycznej mocą, która zmienia i przeobraża struktury konstytuujące cały horyzont pojęciowy.

Lenin Althussera jest w rzeczywistości złym punktem odniesienia, jeśli chcemy zrozumieć rolę, jaką ten pierwszy odegrał w myśli Negriego. W obszarze filozofii francuskiej znajdziemy jednak o wiele lepsze porównanie - spójrzmy, w jaki sposób Nietzsche został „ponownie odkryty” przez takich teoretyków jak Gilles Deleuze czy Michel Foucault ${ }^{11}$. Przez pryzmat ich interpretacji, podobieństwa między Leninem a Nietzschem stają się, paradoksalnie, uderzające. Oto cztery najważniejsze z nich: 1) kluczowe znaczenie filozofii woli, 2) materialna konstytucja podmiotowości, 3) ogromna, destrukcyjna siła krytyki totalnej i jednocześnie wspaniała, konstruktywna moc afirmacji podmiotu, 4) a co za tym idzie ponowne ufundowanie ontologii w wolności. Argumentowaliśmy już wcześniej, że kiedy Deleuze zajmuje się Nietzschem, używa pozytywnego dynamizmu logicznego, (który rozwiną $\mathrm{w}$ studiach nad Bergsonem) w nowym ujęciu - w materialnym polu sił, zgodnie z którym wszystkie kwestie logiczne są sprowadzone do sensów i wartości12. W efekcie, Deleuze odnajduje u Nietzschego logikę woli i wartości, która wprawia w ruch pole podmiotowych sił. Nietzsche dokonuje materialistycznej redukcji - w swoich filozoficznych

$11 \mathrm{Na}$ marginesie, z prac Louisa Fischera (1964) wiemy, że Lenin de facto czytał Nietzschego. Pytanie o wpływ jest tu jednak zupełnie bezzasadne. Podobieństwo Lenina i Nietzschego nie jest dla nas tak interesujące; ważne jest to, że obaj odegrali podobną rolę w rozwoju intelektualnym Deleuze'a i Negriego. Wydaje mi się, że podobnie należy patrzeć na studia Foucaulta nad Nietzschem: pozwoliły mu one odejść od strukturalistycznej siatki pojęciowej i sprawiły, że w centrum zainteresowań pojawiły się pytania o władzę i podmiotowość. Innymi słowy, moglibyśmy powiedzieć, że ruch od ratio cognoscendi do ratio essendi dokonuje się także w okresie między Archeologią wiedzy (1969, ang. tłum. 1972 pol. tłum. 1977) a Nadzorować i karać (1975, ang. tłum. 1979 pol. tłum. 1993). Ta hipoteza wymaga jeszcze szerszego rozważenia [nota wydawcy: patrz przypis 17].

12 Nota wydawcy: W rozdziale 2, Hardt 1993. 
badaniach wszystkie kwestie sprowadza do pytań o władzę i podmiotowość. W języku deleuzjańskim można by powiedzieć, że pytanie „co?” zamienia na pytanie: „kto?”. Nie pyta bowiem „czym jest sprawiedliwość?” ale „kto jest sprawiedliwy?” albo lepiej: „kto chce sprawiedliwości?”. Podobieństwo z Leninem czytanym przez Negriego objawia się w tym, że siły podmiotowe poruszaja, ożywiaja i mają wpływ na wszystkie inne problemy; ta ogromna siła woli jest fundamentem, na którym opierają się rozważania teoretyczne zarówno Lenina, jak i Nietzschego. Widzimy to wyraźnie, kiedy spojrzymy na kwestię „krytyki totalnej”, którą opisaliśmy wcześniej13. Obaj posługują się dosyć niezwykłą koncepcją antagonizmu, która pozwala im na krytykę inicjowaną przez pars destruens, destrukcyjną siłę, tak gwałtowną, że zmiata cały zastany horyzont rozważań, niszcząc doszczętnie bieżący stan rzeczy. Drugą fazą krytyki jest moment pars construens, w którym skonstruowany zostaje nowy horyzont, bez żadnego odniesienia do metafizyki - tym razem horyzont rozważań oparty jest tylko na konstruktywności immanentnych sił podmiotowych. Po tej przerażającej, absolutnej destrukcji, którą przeprowadza Nietzsche, nadchodzi równie poruszająca moc Nietzscheańskiej afirmacji: sztuka rewolty i sztuka organizacji. Najważniejszą kwestią wydaje się być tu współzależność obu tych momentów: ten drugi, związany z siła przyszłych konstrukcji, wyzwala każdego autora, by przeprowadził niczym nieograniczoną destrukcję tego, co teraźniejsze. I podobnie, kiedy już w pierwszej fazie teren zostanie oczyszczony, druga faza objawia się w wolności tworzenia nowego świata, w nieskrępowanej kreatywności.

Na tym właśnie polega radykalność i ogrom wizji, która u Negriego i Deleuze'a pojawia się po „cięciu podmiotowym”: jest ona przywróceniem ontologii. W tym sensie załamuje się opozycja między wolnością a koniecznością. Byt jest nieustannie niszczony i stwarzany na nowo, zmienia się w zależności od ruchów sił podmiotowych. Materialne pole sił ma charakter konfliktowy. Wyznacza też jedyny teren dla ontologii, a przez to byt, który utracił swoje transcendentalne osadzenie, zyskuje dynamiczną plastyczność. Możemy więc przeprowadzić niczym nieograniczony atak na świat, całkowicie zniszczyć byt. Wiemy bowiem, że dzięki sile woli, dzięki naszym materialnym, podmiotowym siłom, możemy zbudować nowy świat, ponownie stworzyć byt. Zdekonstruujemy więc naturę, która została nam dana, aby z naszych marzeń i potrzeb, ukształtować druga, trzecią i n-tą naturę. Przy takim spojrzeniu na ontologię, natura jest zawsze już sztuczna, w tym sensie, że została

13 Nota wydawcy: Ibid. pars destruens jest krokiem destruktywnym, po którym następuje ruch konstruktywny, kreatywny, pars construens; Hardt przejmuje te pojęcia z filozofii scholastycznej. 
skonstruowana przez podmiotowe siły: byt, który się nam jawi i nas określa, sam jest już uwarunkowany i podatny na nasze formowanie. Pole mocy i podmiotowości zajmuje u Lenina i Nietzschego szczególne, teoretyczne miejsce. To właśnie pozwala na zmianę modelu ontologii. U Negriego i Deleuze'a mamy do czynienia z zerwaniem, związanym z wyłonieniem się podmiotowości - zerwanie to należy określić mianem cięcia ontologicznego, nie epistemologicznego. Patrząc na to scholastycznie, ratio essendi zostaje wywyższone nad ratio cognoscendi (podkreślaliśmy to wielokrotnie w naszej pracy o Deleuze'ie $\left.{ }^{14}\right)$. Dlaczego jednak używamy jeszcze terminu „ontologia”, po tym, kiedy byt został wyrwany ze swojej bezwarunkowości? Czy nie byłoby właściwiej - po ogłoszeniu absolutnej plastyczności podmiotu - porzucić dyskurs bytu i przyznać się do czystego relatywizmu? Czy mamy tu do czynienia ze zwrotem postmodernistycznym? W żadnym wypadku! Jest wręcz dokładnie odwrotnie. Istnieje przecież bogata tradycja, od Leopardiego do Lukácsa, która opowiada się za materialistycznym odczytaniem bytu w obrębie tego, co uwarunkowane, w obrębie drugiej natury. Zarówno dla Negriego jak i Deleuze'a, interwencje podmiotu powodują tylko, że dyskurs ontologiczny staje się bardziej adekwatny i ważniejszy dla ich projektów. To, że byt został ukształtowany przez wcześniejsze stosunki sił, nie oznacza, że staje się dla nas mniej substancjalny. Powiedzmy raczej za Nietzschem: „już nie zwrot pokorny »wszystko jest tylko subiektywne«, lecz »jest ono też naszym dziełem! bądźmy dumni z niego!«” (Nietzsche 2009, 314). W tym kontekście tradycyjna opozycja między koniecznością i wolnością zdaje się tracić sens, chociaż pojęcia te wciąż utrzymują swoje znaczenie. W zasadzie cała nasza wolność sprowadza się do tego, czy potrafimy doprowadzić do pęknięcia w bycie, czy potrafimy zniszczyć i ponownie stworzyć naturę, czyli ustanowić konieczność! Dla Lenina i Nietzschego, podmiot nie jest już tylko natura naturata, ale także natura naturans ${ }^{15}$.

$\mathrm{Na}$ tym etapie w ramach studiów nad Leninem widzimy tylko wstępny szkic dyskursu ontologicznego. Negri rozwinie go wyczerpująco i gruntownie w swoich pracach o Spinozie i Leopardim. Pamiętajmy jednak, że ta ontologia ma swoje źródła właśnie tutaj - w erupcji walk społecznych, w wyłanianiu się silnego podmiotu rewolucyjnego, w radykalnej mocy

14 Nota wydawcy: Terminy te, które Deleuze przejmuje z filozofii scholastycznej w swojej pracy o Nietzschem (patrz rozdział 5, Deleuze 2012), odnoszą się do niezbywalnej istotydanej rzeczy jako obiektu poznania.

15 Nota wydawcy: Kolejne pojęcia scholastyczne - natura naturata jest natura pasywną, przeszłą w swoim już-skonstruowaniu, będąca wynikiem. Natura naturans jest naturą w aktywności, w teraźniejszym procesie stwarzania. 
totalnej krytyki. Siła klasy robotniczej jako podmiotu pozostanie na zawsze fundamentem ontologii Negriego.

\section{Podmiot, który niszczy państwo: Lenin i Paszukanis}

Jak pamiętamy, studia Negriego nad Leninem podzieliliśmy na trzy fazy. Na razie omówione zostały dwie: ta dotycząca spontanicznego działania robotników (1890-1900) i ta, która dotyczy organizacji (1900-1910). Obie tworzyły uzupełniające się wzajemnie drogi dojścia do leninowskiej teorii podmiotu. Zajmijmy się teraz trzecią fazą (1910-1917), która w dużej mierze stanowi konsekwencję i praktyczne rozwinięcie leninowskiej teorii podmiotu. Kluczowym motywem tego okresu stanie się obumieranie państwa, a czołowym tekstem Państwo $i$ rewolucja. Negri poświęca wiele miejsca temu dziełu i zajmuje się nim bardzo szczegółowo. Skupimy się jednak tylko na dwóch argumentacjach, ważnych dla naszego wywodu: 1) na czym polega zniszczenie państwa? 2) oraz: w jaki sposób tak radykalna destrukcja jest w ogóle możliwa? Właśnie w tym miejscu, w leninowskiej wizji rewolucji, widać konstytuującą ontologię wspólną Leninowi i Nietzschemu. Widać, jak działa ona na materialnym, politycznym terenie.

Zniszczenie państwa jest pierwszym krokiem do rzeczywistego ukształtowania się siły robotniczej, do powstania komunizmu (Negri 1976, 152). Stanowisko Lenina jest tutaj jasne. Jednak Negri podkreśla, że leninowska teoria państwa była często źle interpretowana, ponieważ państwo rozumiano w niej zbyt wąsko - jedynie jako aparat represji. Dlatego też zanim zaczniemy zastanawiać się nad zniszczeniem państwa, musimy zastanowić się czym ono jest, musimy dookreślić obiekt rzeczywistego antagonizmu robotników. „Państwo jest siłą zewnętrzną wobec społeczeństwa, efektem nierozwiązywalności konfliktów" (Negri 1976, 135). Możemy zacząć od Engelsowskiej definicji16, w świetle której państwo jest siła przymusu transcendentną wobec społeczeństwa, która ma narzucać kapitalistyczną dominację i negować napięcie walk klasowych. Jest onieśmielająca siła, która rozgrywa konflikt społeczny. Państwo nie jest tylko organem kapitalistycznego panowania; używa bowiem prawa, by organizować proces pracy. Mamy więc do czynienia ze skomplikowanym splotem

16 Negri zauważa, że Lenin zajmuje się Engelsowską teorią państwa z pewnym dystansem. To prawda, praca Engelsa jest mało przydatna zarówno dla Lenina, jak i dla nas: jest pisana z niewłaściwej, naturalistycznej perspektywy i opiera się na bardzo podejrzanych, antropologicznych argumentach. Engels pomija rolę państwa w polu kapitalistycznego prawa wartości i organizacji pracy. Rekonstrukcja myśli Marksa na temat państwa okazuje się o wiele bardziej użyteczna. 
panowania i organizacji. Dlatego też państwo wykorzystuje zarówno aparat represji, jak i mechanizmy prawne, co Negri opisuje jako działanie w obrębie „konstytucjonalizacji pracy” i „prawa wartości”.Lenin dostrzega bardzo wyraźnie, że państwo musi zostać zniszczone nie tylko jako transcendująca siła, ale przede wszystkim w swojej materialnej bazie (rozdział 5 Państwa $i$ Rewolucji). Po to, by znieść pracę czy kapitalistyczne stosunki pracy (Negri 1976, 156). Dlatego właśnie Negri uzupełnia analizy Lenina o Marksowski argument z Zarysu krytyki ekonomii politycznej, dotyczący wyczerpania się prawa wartości opartego na pracy (Negri 1976, 164-169). Według Negriego kwestie te nie tylko ze sobą współgrają, ale stają się niebywale spójne, gdy rozważamy je razem.

Problem materialnej bazy państwa i jego destrukcji zostaje szczegółowo omówiony w jeszcze innej pracy Negriego z tego okresu: Rileggendo Pasukanis: note di discussione (Czytając ponownie Paszukanisa: Notatki do dyskusji) (Negri 1977). Paszukanis, zamordowany w czystkach stalinowskich, jeden z głównych sowieckich teoretyków prawa z lat 20. XX wieku, jest jednym z niewielu, którzy - jak twierdzi Negri - rozwijali Marksowskie i Leninowskie intuicje dotyczące filozofii prawa ${ }^{17}$. Warto odejść na chwilę od samego Lenina i zagłębić się w teorię Paszukanisa, która wedle Negriego ukazuje napięcia związane z dyskursem obumierania państwa. Punktem wyjścia jest tu rozpoznanie, że współczesne prawo nie jest obojętnym, racjonalnym schematem - nie polega też na abstrakcyjnym narzucaniu przemocy i siły. Jest za to nierozerwalnie związane z organizacją stosunków dotyczących wymiany towarowej: „Podobnie jak bogactwo społeczeństwa kapitalistycznego przybiera formę ogromnego nagromadzenia towarów, samo społeczeństwo stanowi nieskończony łańcuch stosunków prawnych” (Paszukanis 1985, 73). Następnie Paszukanis usiłuje rozwinąć teorię prawa idąc za wzorem Marksa, stara się odczytywać prawną logikę społecznych stosunków wymiany. Negri stwierdza, że Paszukanis ma w zasadzie rację, kiedy postrzega prawo jako kombinację dwóch funkcji: społecznej organizacji produkcji i władzy nad stosunkami społecznymi. Zaznacza jednak, że pojęcie prawa powinniśmy łączyć nie tylko z dziedziną towarów, ale także z prawem wartości (Negri 1977, 170). Wraz z rozwojem kapitału prawo w społeczeństwie ma tendencję do ciążenia w stronę funkcji panowania.

17 Negri podkreśla, że Paszukanis jest jednym z pierwszych (i niestety jednym z ostatnich), którzy przyjęli prawdziwie marksowską perspektywę $\mathrm{w}$ dziedzinie teorii prawa: analizy Laska i Lukácsa pokrywają się częściowo z badaniami Paszukanisa (Negri 1973c: 164). Więcej o roli, jaką Paszukanis odegrał w filozofii radzieckiej można znaleźć w doskonałej przedmowie Johna Hazarda do Soviet Legal Philosophy (red. Hazard 1951). Paszukanis dookreśla swoje stanowisko w polemice z pracami Stučki, rosyjskiego marksisty i Hansa Kelsena, austriackiego neokantysty. 
Ponadto, dzięki powyższemu złączeniu, prawo jest blisko związane z wytwarzaniem wartości dodatkowej (Negri 1977, 172). Wartość dodatkowa względna jest Marksowskim pojęciem, które określa normatywną zdolność kapitalistycznych relacji produkcji i która określa tę normatywność jako wyzysk i dominację. „Prawo i proces wyciskania wartości dodatkowej. Ale burżuazyjna forma prawa, w całym swoim skomplikowaniu, rozciaga kontrole nad aktualnością procesu rozwoju wartości dodatkowej względnej, nad artykulacją organizacji i przemocy, nad produkcją i panowaniem"(Negri 1977, 174). Prawo burżuazyjne jest tylko przejawem kapitalistycznego wytwarzania wartości dodatkowej. Widać więc, jak ogromny zakres ma leninowskie wezwanie do zniszczenia państwa. Działanie to nie polega jedynie na zdemontowaniu państwowego aparatu przemocy, ale także na zniesieniu burżuazyjnego prawa i społecznych stosunków produkcji, które je konstytuują. „Idąc za dobrą Marksowską intuicją, Paszukanis nie ma watpliwości, że prawo nie jest tylko formą społeczeństwa kapitalistycznego, ale że jest też jego formą nieodłacz̨a”' (Negri 1977, 188). Całościowa krytyka kapitału musi więc zmierzyć się ze źródłem problemu: zniesienie państwa wymaga zniesienia prawa, a zniesienie prawa wymaga zniesienia prawa wartości, zniesienia samych stosunków pracy (Negri 1977, 191). „Walka komunistyczna staje się automatycznie walką przeciwko pracy, przeciwko państwu, przeciwko prawu, które ustanawia specyficzna, autorytarną formę stosunków między państwem a organizacją pracy" (Negri 1977, 192). Związek Radziecki, który Paszukanis znał z lat dwudziestych XX wieku, poczynił w tę stronę dopiero pierwsze kroki: dlatego ówczesne społeczeństwo radzieckie byłe przez niego określane jako „kapitalizm państwa proletariackiego”. Faktycznie, pars destruens Rewolucji i przechodzenia do komunizmu, która znajdziemy zarówno u Lenina, jak i u Paszukanisa, jest o wiele bardziej radykalna, ma o wiele większy zasięg. Dokonując inwersji heglowskiej logiki, możemy powiedzieć, że zniesienie państwa jest także zniesieniem społeczeństwa, które je podtrzymuje.

Głębia i moc leninowskiej pars destruens domaga się postawienia pytania, którym mieliśmy się zajać w drugiej kolejności: jak możliwe jest takie zniesienie? Czy myśl o doszczętnym zniszczeniu burżuazyjnych i kapitalistycznych mechanizmów porządku społecznego nie jest kompletnie utopijna? I czy taki ruch, nawet gdyby był możliwy, nie prowadziłby do anarchii i rozlewu bezcelowej przemocy? Czy nie oznaczały powrotu do stanu natury? Kwestia ta odsyła nas do podstawowej opozycji, która pozostaje kluczowa dla filozofii polityki przynajmniej od XVII wieku i którą często rozpatruje się w kontekście 
demokracji18. Perspektywa leninowska, a więc stanowisko, które opowiada się za zniesieniem państwa, może być utrzymane tylko wówczas, gdy oprze się je na sile materialnego podmiotu społecznego, zdolnego do oddolnego rządzenia społeczeństwem. Państwo nie obumrze samo z siebie, na mocy funkcjonowania jakichś obiektywnych praw sprzeczności; musi pojawić się podmiot, który - odpowiednio przygotowany - zniszczy to państwo. Uściślając nieco nasze rozważania: trzecia faza myśli Lenina, która znajduje swój wyraz w Państwie $i$ rewolucji, jest możliwa tylko na bazie dwóch pierwszych, w których ustanowiona została siła klasy robotniczej i jej zdolność do kształtowania nowych porządków społecznych. Innymi słowy, nieokiełznana moc pars destruens może zostać wyzwolona dopiero wtedy, gdy zostanie zweryfikowana siła sprawcza pars construens, autonomicznego podmiotu społecznego. Pomysł, aby zniszczyć odgórny porządek społeczny, narzucony przez państwo kapitalistyczne, jest faktycznie anarchistyczny i utopijny - o ile nie opiera się na rzeczywiście istniejącej, społecznej, podmiotowej zdolności do oddolnego rządzenia. Lenin utrzymuje, że dopóki funkcjonuje państwo, nie będzie wolności; a kiedy jest wolność, oznacza to, że nia ma już państwa. Tę leninowską wolność można chyba najlepiej ujać jako dobrze rozwiniętą anarchię, w której organizacji ujawnia się w pełni podmiotowość klasy robotniczej. „Bojowy i rewolucyjny komunizm jest prawdziwym anarchizmem” (Negri 1976, 163). Wolność Leninowska wynosi anarchię do rangi prawdy, czy może lepiej - podnosi anarchię do poziomu demokracji.

Powyższe analizy dobiegły końca: dotarliśmy do kolejnego punktu zwrotnego w myśli Negriego. Widzieliśmy, w jaki sposób ożywił on tradycję rewolucyjną i podniósł kwestię rewolty i oporu - w całej rozległości tego zagadnienia. Ale zamknięcie pewnych wątków wymaga otwarcia innych: w dyskursie rewolucyjnym kryją się już pewne pytania, na które trzeba odpowiedzieć. Jeżeli mamy doprowadzić do zniszczenia kapitału, jego państwa, procesu wytwarzania wartości, organizacji społecznej - w skrócie, całego obecnego stanu

18 Najlepszym przykładem tej dychotomii w historii filozofii politycznej jest opozycja między Hobbesowską propozycją władzy państwowej a Spinozjańską koncepcją demokracji. Spinoza stara się sprecyzować te różnice w liście 50 (do Jellesa, Spinoza 1961,231-233), w którym argumentuje, że nikt nie może scedować na kogoś innego swojej władzy sądzenia - podobnie rzecz ma się z władzą. Najważniejsza kwestia jest być może najlepiej wyłożona w Traktacie politycznym, II 4 (Spinoza 2003), kiedy Spinoza podkreśla, że każda umowa czy kontrakt są ważne tylko dopóki obie strony chcą żeby tak było. To skuteczne odrzucenie umowy społecznej jako konstrukcji transcendentalnej władzy staje się podstawą do odrzucenia Hobbesowskiej wizji państwa; oczywiście, jest ono możliwe tylko ze względu na siłę multitudo jako podmiotu do demokratycznego tworzenia społeczeństwa. W swoim studium o Spinozie Negri ujmuje tę polityczną i filozoficzną dychotomię przez pryzmat różnicy między potestas a potentia. Wrócimy do tego zagadnienia później [Nota wydawcy: w ostatnim rozdziale pracy doktorskiej Hardta, „The Constitution of Communism (1973-1978)”]. Odniesienie do Lenina jest jednak oczywiste: umiejętność zniszczenia transcendentnej władzy państwa ma swoje źródło w materialnej zdolności mas jako podmiotu, do tworzenia demokratycznego porzącku społecznego. 
rzeczy - to co wypełni pustkę po nim? Jakie są wewnętrzne mechanizmy tej radykalnej, proletariackiej demokracji? Co to za nowe środki wytwarzania wartości i nowe normy, wedle których organizować ma się społeczeństwo? Jaka jest wewnętrzna i autonomiczna istota tego nowego podmiotu i co właściwie proponuje on jako konstytuujące dla sił społecznych? Innymi słowy, w jakim kształcie odrodzi się byt społeczny? Na tym etapie Negri nie ma jeszcze odpowiedzi na powyższe pytania. Jedyne co może powiedzieć, to, że „pierwsze i ostatnie słowo należy do mas. Jak zawsze.” (Negri 1976, 162). Oczywiście, dobrze zaznaczyć już na początku, że każda odpowiedź musi wyrosnąć na demokratycznym gruncie - ale to w żadnym razie nie wyczerpuje problemu. Podmiot, siła i byt: te trzy kwestie wyznaczają oś, wokół której krążyć będzie refleksja Negriego. W następnej fazie swoich badań będzie musiał odejść od pars destruens i skupić się na pars construens: na tym, co owe trzy rzeczy konstytuuje. 


\section{Wykaz literatury}

Alquati, Romano. 1975. Sulla FIAT e altri scritti. Milan: Feltrinelli.

Althusser, Louis. 1971. Lenin and Philosophy. Tłum. Ben Brewster. New York: Monthly Review.

Bocca, Giorgio. 1980. Il caso 7 aprile: Toni Negri e la grande inquisiz̨ione. Milan: Feltrinelli.

Borio, Guido, Francesca Pozzi i Gigi Roggero. 2002. Futuro anteriore. Dai 'Quaderni Rossi' ai movimenti globali: ricchezze e limiti dell'operaismo italiano. Rome: Derive Approdi.

Deleuze, Gilles. 2012. Nietzsche i filozofia. Tłum. Bogdan Banasiak. Łódź: Wydawnictwo Oficyna.

Hardt, Michael. 1993. Gilles Deleuze: An Apprenticeship in Philosophy. Minneapolis: University of Minnesota Press.

red. Hazard, John. 1951. Soviet legal philosophy. Cambridge: Harvard University Press

Lenin, Włodzimierz. 1985. „Co robić? Palące zagadnienia naszego ruchu.” W Włodzimierz Lenin, Drieta wszystkie, tom 6. Warszawa: Książka i Wiedza.

Marks, Karol. 1986. Zarys krytyki ekonomii politycznej. Tłum. Zygmunt Jan Wyrozembski. Warszawa: Książka i Wiedza.

Negri, Antonio. 1974. „Partito operaio contro il lavoro.” W Sergio Bologna, Paolo Carpignano i Antonio Negri, Crisi e organizzazione operaia. Milan: Feltrinelli.

Negri, Antonio. 1976. La fabbrica della strategia: 33 lezioni su Lenin. Padua: CLEUP/LibriRossi.

Negri, Antonio. 1977. „Rileggendo Pasukanis: note di discussion.” W La forma stato. Milan: Feltrinelli.

Negri, Antonio et al. 1983. „Do You Remember Revolution?” W Revolution Retrieved. London: Red Notes.

Negri, Antonio. 1988. „Crisis of the Planner-State: Communism and Revolutionary Organization." W Revolution Retrieved: Writings on Marx, Keynes, Capitalist Crisis and New Social Subjects (1967-83). London: Red Notes.

Nietzsche, Fryderyk. 2009. Wola mocy. Tłum. Konrad Drzewicki, Stefan Frycz. Kraków: visà-vis/etiuda.

Paszukanis, Jewgienij. 1985. Ogólna teoria prawa a marksižm. Tłum. Ludwika Lisiakiewicz. Warszawa: PWN.

Piotte, Jean-Marc. 1986. „Le cheminement politique de Negri.” W Actes du Colloque de Montreal, L'Italie: le Philosophe et le Gendarme, red. Marie-Blanche Tahon i André Corten. Montreal: VLB Editeur.

Spinoza, Benedykt. 1961. Listy. Tłum. Leszek Kołakowski. Warszawa: Państwowe Wydawnictwo Naukowe.

Spinoza, Benedykt. 2003. Traktaty. Tłum. Ignacy Myślicki. Kęty: Wydawnictwo Antyk.

Wright, Steven. 2002. Storming Heaven: Class Composition and Struggle in Italian Autonomist Marxism. London: Pluto Press. 
Michael Hardt - amerykański filozof polityki i teoretyk literatury. Absolwent inżynierii (pracował w Ameryce Łacińskiej, popularyzując alternatywne źródła energii) i komparatystyki literackiej. Autor Gilles Deleuze: an Apprenticeship in Philosophy (1993) oraz czterech książek napisanych wspólnie z Antonio Negrim: Labor of Dionysus: a Critique of the State-form (1994), Imperium (2000, polskie wydanie 2005), Multitude: War and Democracy in the Age of Empire (2004), Commonwealth (2009, polskie wydanie 2012).

CYTOWANIE: Hardt, Michael. 2016. Do fabryki! Lenin Negriego i cięcie podmiotowe (1968-73). Praktyka Teoretyczna 2 (20). 194-228.

DOI: $10.14746 /$ prt.2016.2.7 